\title{
Petrogenesis and geochronology of a post-orogenic calc-alkaline magmatic association: the Žulová Pluton, Bohemian Massif
}

\author{
Antonin LAURENT ${ }^{1,2 *}$, Vojtěch JANOUŠEK ${ }^{2,3}$, Tomáš MAGNA², Karel SCHULMANN ${ }^{2,4}$, \\ Jitka MÍKOVÁ ${ }^{2}$ \\ ${ }^{1}$ Géosciences Environnement Toulouse (GET), Observatoire de Midi-Pyrenées, Université de Toulouse, CNRS, IRD, 14 avenue Edouard \\ Belin, 31400 Toulouse, France; antonin.laurent@get.obs-mip.fr \\ ${ }^{2}$ Czech Geological Survey, Centre for Lithospheric Research, Klárov 3, 11821 Prague 1, Czech Republic \\ ${ }^{3}$ Institute of Petrology and Structural Geology, Charles University, Albertov 6, 12843 Prague 2, Czech Republic \\ ${ }^{4}$ EOST, Institut de Physique de Globe, UMR 7516, Université de Strasbourg, 1 Rue Blessig, 67084 Strasbourg, France \\ * Corresponding author
}

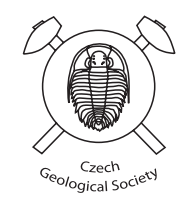

The Žulová Composite Pluton located at the north-eastern margin of the Bohemian Massif exposes undeformed coexisting mafic-felsic association typical of post-orogenic magmatism. The bulk of the pluton is made of biotite granite and granodiorites along with subordinate quartz monzodiorite. New LA-ICP-MS U-Pb zircon dating revealed a synchronous emplacement of the biotite granite ( $291 \pm 5 \mathrm{Ma})$, granodiorite and quartz monzodiorite $(292 \pm 4 \mathrm{Ma})$. The whole-rock geochemistry and the $\mathrm{Sr}-\mathrm{Nd}$ isotopic data indicate that a plausible source for the biotite granite and the granodiorite could have been a lithologically inhomogeneous pile of Devonian arc-derived, immature metagreywackes interbedded with volcaniclastics. Melting of this crustal material was probably triggered by the rise of hot basic (quartz monzodioritic) magma which could have been an enriched mantle-derived melt contaminated by the underlying Cadomian basement. The Žulová Composite Pluton is a part of a Late Carboniferous-Early Permian Sudetic Granite Belt, including in addition three large plutonic complexes distributed along major terrane boundaries: the Krkonoše-Jizera, the Strzegom-Sobótka and the Strzelin massifs. The genesis of this magmatic belt was likely induced by the rise of hot mantle-derived magma in the crust while their spatially and temporally discrete emplacement at shallow levels was probably related to the (extensional) reactivation of lithospheric discontinuities at terrane boundaries. Former orogenic wedges, resulting from the inversion of youthful plate margins, represent a feasible fertile source for such post-orogenic granitoids.

Keywords: post-orogenic magmatism, geochemistry, U-Pb geochronology, Bohemian Massif, Sudetic Granite Belt Received: 28 April 2014; accepted: 8 October 2014; handling editor: F. Finger

The online version of this article (doi: 10.3190/jgeosci.176) contains supplementary electronic material.

\section{Introduction}

The late stages of orogenic systems are characterized by a discrete magmatic activity immediately post-dating the main collisional event and continuing for further up to $40 \mathrm{My}$ (Turner et al. 1992). The plutons produced during these magmatic events, referred to as post-collisional and subsequently post-orogenic, differ from the preceding syn-collisional suites in that they have more primitive radiogenic isotopic compositions and often bimodal petrology (Bonin et al. 1998). During collision, the continental crust is strongly reworked by imbrication of tectonic units derived from different crustal levels while the lithospheric mantle may have been modified (or not) by preceding subduction. As a consequence, extremely variable rock-types, ranging from silicic peraluminous to high-K calc-alkaline or alkaline suites (e.g., Sylvester 1989, 1998; Liégeois et al. 1998), may arise due to the variability of the potential sources. A mantle contribution, at least as a heat source, is generally invoked (see Bonin
2004 for a review). The genesis of post-orogenic granitoids after 10 to $30 \mathrm{My}$ of magmatic and metamorphic quiescence remains an intriguing problem.

In the Variscan Bohemian Massif, two post-collisional to post-orogenic magmatic belts have been recognized (Finger et al. 1997, 2009). The more voluminous southern Saxo-Danubian Granite Belt was built up by two magmatic pulses at 330-320 Ma and 317-310 Ma (Siebel et al. 2003; Förster and Romer 2010), perhaps in response to southward progressing mantle delamination (Finger et al. 2009). The northern Sudetic Granite Belt (SGB) is younger (c. 315-290 Ma) and its relation to the Variscan orogeny remains more enigmatic. The SGB is constituted by four composite plutons distributed along the major lithospheric faults forming terrane boundaries in the Sudetes Mts. In this paper we present an integrated geochemical and geochronological study of the Žulová Composite Pluton, which exposes an undeformed coeval felsic-mafic plutonic association in the easternmost part of the SGB. 


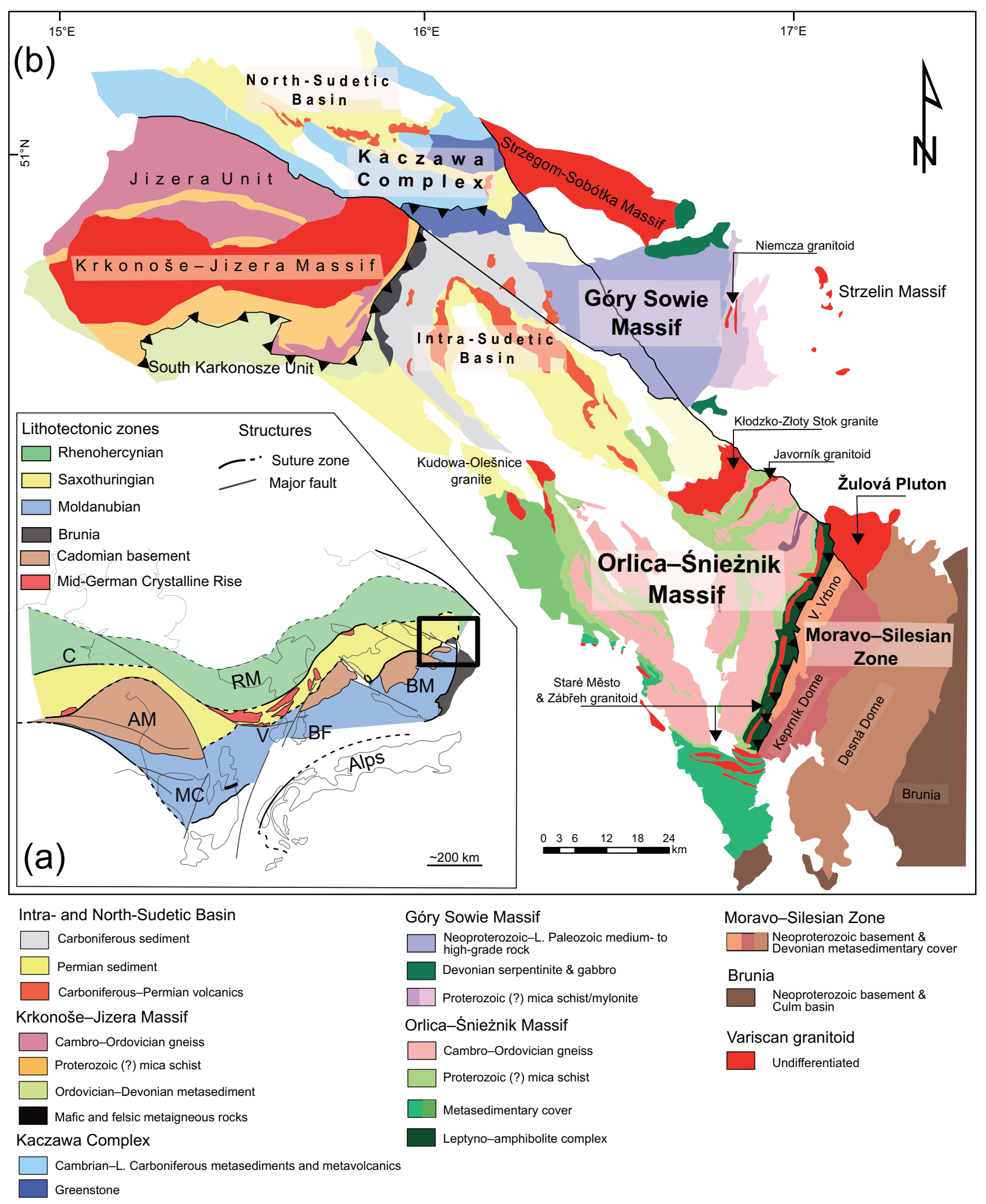

Fig. 1a - Sketch of the Variscan Belt of Europe (modified after Skrzypek et al. 2012). AM = Armorican Massif, BF $=$ Black Forest, BM = Bohemian Massif, $\mathrm{C}=$ Cornwall, $\mathrm{MC}=$ Massif Central, $\mathrm{RM}=$ Rhenish Massif, $\mathrm{V}=$ Vosges. The black rectangle depicts the studied area. $\mathbf{b}-$ Simplified geological map of the Sudetes (modified after Aleksandrowski et al. 1997; Awdankiewicz 2004; Chopin et al. 2012). 


\section{Geological setting}

\subsection{Variscan Orogeny in the Bohemian Massif}

The Variscan Belt in central Europe is the result of the convergence between two macro-continents, Gondwana and Laurussia, lasting from Silurian to Permian (Lardeaux et al. 2014). Subduction processes were active till the Early Carboniferous and led to the accretion of several Gondwana-derived blocks to Laurussia (Matte 1991; Franke 2000). Current model of the geological development in the eastern part of the European Variscan Belt, i.e. the Bohemian Massif, assumes a SE directed (in present-day coordinates) Late Devonian to Early Carboniferous subduction of a Saxothuringian Ocean underneath the easterly Teplá-Barrandian and Moldanubian domains (Fig. 1a; Schulmann et al. 2009). This subduction produced arc-related magmatism in the overriding plate culminating in the development of the Central Bohemian Plutonic Complex at 355-338 Ma (Žák et al. 2014 and references therein). The subduction episode ended with the arrival of the Saxothuringian continental crust into the subduction channel which was associated with crustal thickening and development of the orogenic root (Schulmann et al. 2014b). Subsequently, the indentation of the thickened crustal root by the easterly Brunia microcontinent (Dudek 1980) facilitated the gravitydriven extrusion of lower crustal material accompanied with the emplacement of ultrapotassic plutons (Janoušek and Holub 2007; Schulmann et al. 2014b). Late stages of the orogeny in the northern Variscan realm involved overall dextral strike-slip regime along lithospheric-scale structures such as the Elbe, Bavarian and Intra-Sudetic faults (Edel et al. 2013). Voluminous post-collisional magmatic activity has been recognized, including the southern Saxo-Danubian Granite Belt and the northern Sudetic Granite Belt (Finger et al. 2009 and references therein). From 300 to $270 \mathrm{Ma}$, the tectonic regime in the northern Variscan Belt was extensional, as documented by the development of numerous intra-montane Permian basins (Kroner and Romer 2013).

\subsection{Geology of the Sudetes Mts.}

In the Sudetes Mts. (Fig. 1b), the Saxothuringian subduction beneath the Teplá-Barrandian Unit (presently covered by Permian and Mesozoic sediments) is evidenced by the presence of accretionary prisms (Kryza et al. 2007; Kryza and Pin 2010) containing relicts of Late Devonian blueschists (Maluski and Patočka 1997; Collins et al. 2000; Žáčková et al. 2010; Faryad and Kachlík 2013). The Saxothuringian subduction probably triggered the development of a continental arc and back-arc system further east on the Cadomian Brunian crust (Janoušek et al. 2014 and references therein), known as the MoravoSilesian Zone. This episode was characterized by the deposition of a thick volcano-sedimentary pile (the Vrbno Group) composed of voluminous bimodal volcanics interlayered with quartzites/conglomerates, immature greywackes, graphitic pelites and carbonates (Kalvoda et al. 2008). The bimodal volcanic suite, dated at $~ 374-371$ $\mathrm{Ma}$, is formed by the Western Volcanic Belt, interpreted as a volcanic-arc sequence, and the Eastern Volcanic Belt, the former back-arc, with slices of Cadomian basement in between (Janoušek et al. 2014).

In Sudetes, the influx of the Saxothuringian felsic crust into the orogenic root area also led to crustal thickening and rapid vertical extrusion of the OrlicaŚnieżnik gneiss-dome at c. 340 Ma (Chopin et al. 2012; Mazur et al. 2012). To the east, the docking of Brunia to the Moldanubian domain caused the inversion of the Moravo-Silesian back-arc which resulted in a relatively HT/MP metamorphism typical of the Silesian Zone ( 340 Ma; Košuličová and Štípská 2007). The imbrication of the Cadomian gneissic basement, yielding zircon magmatic ages between 684 and $502 \mathrm{Ma}$ (van Breemen et al. 1982; Kröner et al. 2000; Hegner and Kröner 2000; Żelaźniewicz et al. 2005; Hanžl et al. 2007), with Devonian volcano-sedimentary sequences led to a deep burial (locally eclogite facies; Štípská et al. 2006) of fertile material. The three main units forming the Moravo-Silesian orogenic wedge, the Velké Vrbno upper allochthon, the Keprník lower allochthon and the Desná paraautochthon (Schulmann and Gayer 2000), were subsequently exhumed during Early Carboniferous (Schulmann et al. this volume). The cooling of the Silesian orogenic wedge occurred between 315 and $305 \mathrm{Ma}$ (Maluski et al. 1995). This period also corresponded to large-scale movements along the Intra-Sudetic Fault, Sudetic Boundary Fault and to the onset of extension recorded by the filling of the Intra-Sudetic Basin with erosional products of the Variscan basement and bimodal volcanics (Dziedzic and Teisseyre 1990; Awdankiewicz 2004).

This late tectonic evolution was accompanied by intrusion of four major composite plutons making up the $\mathrm{Su}$ detic Granite Belt (Finger et al. 2009) into the basement of the Moravo-Silesian and Saxothuringian zones. The most voluminous and oldest, 312 Ma Krkonoše-Jizera Massif, intruded the Saxothuringian basement (Kryza et al. 2014a). Its genesis may be explained by the hybridization of crustally-derived granitic magma with large volumes of mantle-derived (lamprophyric) magmas (Słaby and Martin 2008). A mixed crustal-mantle origin is also assumed for the Strzegom-Sobótka Massif ( 309-302 Ma; Pin et al. 1989; Turniak and Bröcker 2002; Turniak et al. 2005b; Domańska-Siuda 2007). The volumetrically minor Strzelin Massif ( 306-291 Ma; Oberc-Dziedzic 1999; Turniak et al. 2005a; Pietranik and Waight 2008; 


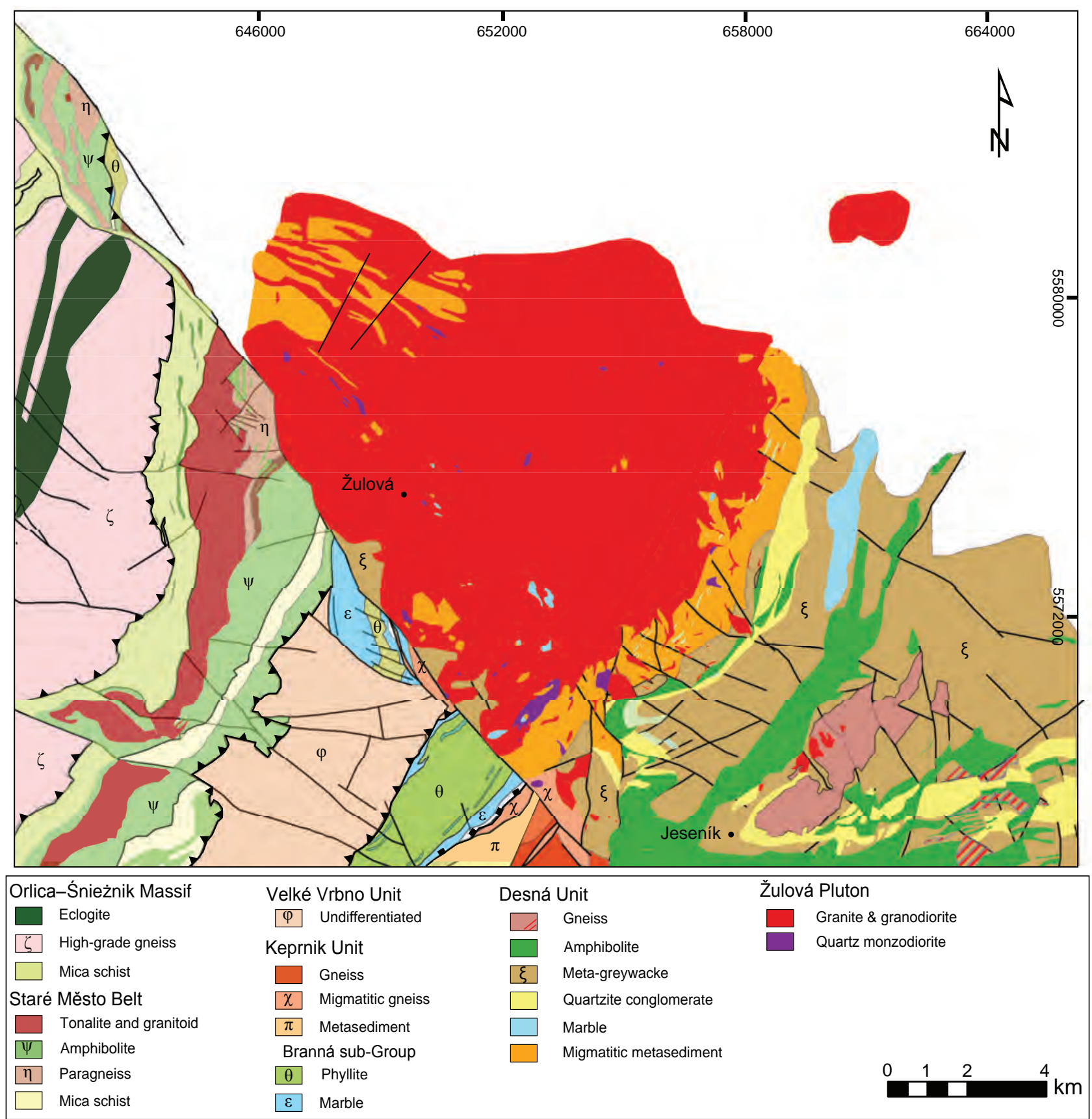

Fig. 2 - Geological map of the Žulová Pluton and its surrounding units (modified after Don et al. 2003; Žaček et al. 2004a, 2005a).

Oberc-Dziedzic et al. 2010, 2013), was emplaced into the Cadomian orthogneiss basement covered by Devonian metasandstones (the so-called Jegłowa beds). These units can be correlated with the Moravo-Silesian Zone (ObercDziedzic et al. 2005; Szczepański 2007).

\section{3. Žulová Composite Pluton}

The Žulová Composite Pluton, located at the eastern extremity of the SGB, intruded the Moravo-Silesian orogenic wedge (Fig. 2). The pluton is delimited to the south-west by the termination of the Intra Sudetic Fault, which disturbed the original stacking pattern by down throwing the southern with respect to the northern block. This segment of the Intra Sudetic Fault was described as an Alpine normal fault by Aleksandrowski et al. (1997) but the nature of the contact between the pluton and mid-crustal rocks (Keprník, Velké Vrbno and Staré Město units) remains ambiguous as several xenoliths found within the pluton are suspected to be derived from these 
units. To the south-east, the contact with the Devonian metasedimentary cover of the Desná paraautochthon is intrusive, causing a $\sim 1 \mathrm{~km}$ wide migmatitized zone within metasediments and a wider peri-plutonic aureole characterized by HT-LP metamorphic assemblage (Cháb and Žáček 1994; Baratoux et al. 2005).

Based on modal compositions as well as whole-rock major- and trace-element chemistry, the Žulová Composite Pluton has been classified as an I-type suite, whose evolution was mainly controlled by fractional crystallization (Zachovalová et al. 2002). Cooling of the granodiorite south-west of Vápenná has been dated by Maluski et al. (1995) $\left({ }^{40} \mathrm{Ar}-{ }^{39} \mathrm{Ar}\right.$ amphibole: $292 \pm 3 \mathrm{Ma}$, biotite: $290 \pm 3 \mathrm{Ma}$ ). Monazite from a pegmatite dyke cutting the pluton yielded a TIMS U-Pb age of $303.4 \pm 1.7 \mathrm{Ma}$ (M. Novák, personal communication, 2014).

\section{Analytical techniques}

Detailed analytical procedures are described in Electronic Supplementary Material 1. Whole-rock major-element analyses were carried out in the Central Laboratory of the Czech Geological Survey, Prague. Trace-elements were analyzed by ICP-MS or ICP-AES (Ba, Sr, Zr, Y, Ni, Co, $\mathrm{Zn}, \mathrm{Cr}$ and $\mathrm{V}$ ) at the LHyGeS Laboratory, Strasbourg.

The Sr-Nd analyses were performed at the Czech Geological Survey (Prague), following standard procedure described in Míková and Denková (2007). The initial $\varepsilon_{\mathrm{Nd}}$ values and single-stage CHUR Nd model ages were obtained using the Bulk Earth parameters of Jacobsen and Wasserburg (1980); the two-stage Depleted Mantle Nd model ages were calculated after Liew and Hofmann (1988).

Zircon dating was carried out at the University of Lausanne (Switzerland) with an Element XR sector-field ICPMS coupled to an UP-193FX laser ablation system (New Wave Research). The U-Pb isotopic ratios of unknown samples, paralleled by data from the reference zircons, are reported in Electronic Supplementary Material 2.

\section{Petrology}

Below, we give a summary of previously published and new data concerning the field relationships and petrography of the four main lithologies distinguished within the Žulová Composite Pluton. Detailed petrography and mineral chemistry are reported in Electronic Supplementary Material 3.

\subsection{Biotite granite}

Medium-grained $(2-7 \mathrm{~mm})$ biotite granite with hypidiomorphic texture constitutes much of the pluton. The main constituents are (in vol. \%): quartz (23-48), K-feldspar (25-44), plagioclase (13-31), biotite (4-7) and traces of muscovite $(<1)$, with accessory ilmenite, apatite, zircon and rare allanite and monazite. Locally, continuous variations in biotite contents and in feldspar grain size (up to $1.5 \mathrm{~cm}$ ) are observed, as well as K-feldspar and biotite crystals accumulation (Fig. 3g). Several amphibole-biotite mafic microgranular enclaves (MME, Barbarin and Didier 1992) and rare biotite schlieren are exposed in active quarries. Numerous metasedimentary xenoliths or screens are found, ranging from several centimeters to several tens of meters across (Fig. 3a). Late sub-horizontal aplitic and pegmatitic veins, $1-5 \mathrm{~m}$ thick, are common.

\subsection{Starost granodiorite}

The fine-grained $(<1 \mathrm{~mm})$ Starost granodiorite is grey in colour and occurs only around the town of Žulová. The rock is isotropic with hypidiomorphic texture. Typical assemblage is (in vol. \%) quartz (25-35), K-feldspar (20-27), plagioclase (35-40), biotite (7-12) and amphibole (2-3). Accessories are represented by sphene, apatite, zircon, allanite, ilmenite and secondary chlorite and sericite. Centimetre- to decimetre-sized angular xenoliths of biotite granite are found within the Starost granodiorite; the contacts are always sharp (Fig. 3b-c).

\subsection{Dark granodiorite}

The dark granodiorite is fine to medium grained (0.5$2 \mathrm{~mm}$ ) and is found along the western margin of the pluton. The dark granodiorite has the same mineral assemblage as the Starost type but with more biotite (8-14 vol. \%) and amphibole (4-11 vol. \%).

\subsection{Quartz monzodiorite}

The quartz monzodiorite to monzogabbro forms mostly enclaves several $\mathrm{cm}$ to several dozens of meters across, enclosed within the biotite granite. This rock type also forms isolated bodies within migmatized metasedimentary units along the south-eastern margin of the pluton. The bodies are macroscopically rather heterogeneous, exhibiting variable grain size $(0.5-8 \mathrm{~mm})$, textures and proportions of mafic minerals (Fig. 3f). The fine-grained quartz monzodiorite shows locally a macroscopically well-developed sphene-centred ocellar texture (Vegas et al. 2011) consisting of leucocratic ocelli with brownish sphene crystals in the centre, enclosed in a biotite-rich matrix.

Within the main granitic body occurs homogeneous coarse-grained quartz monzodiorite with doleritic texture (Fig. 3i). Typical assemblage is (vol. \%) quartz (10-20), 

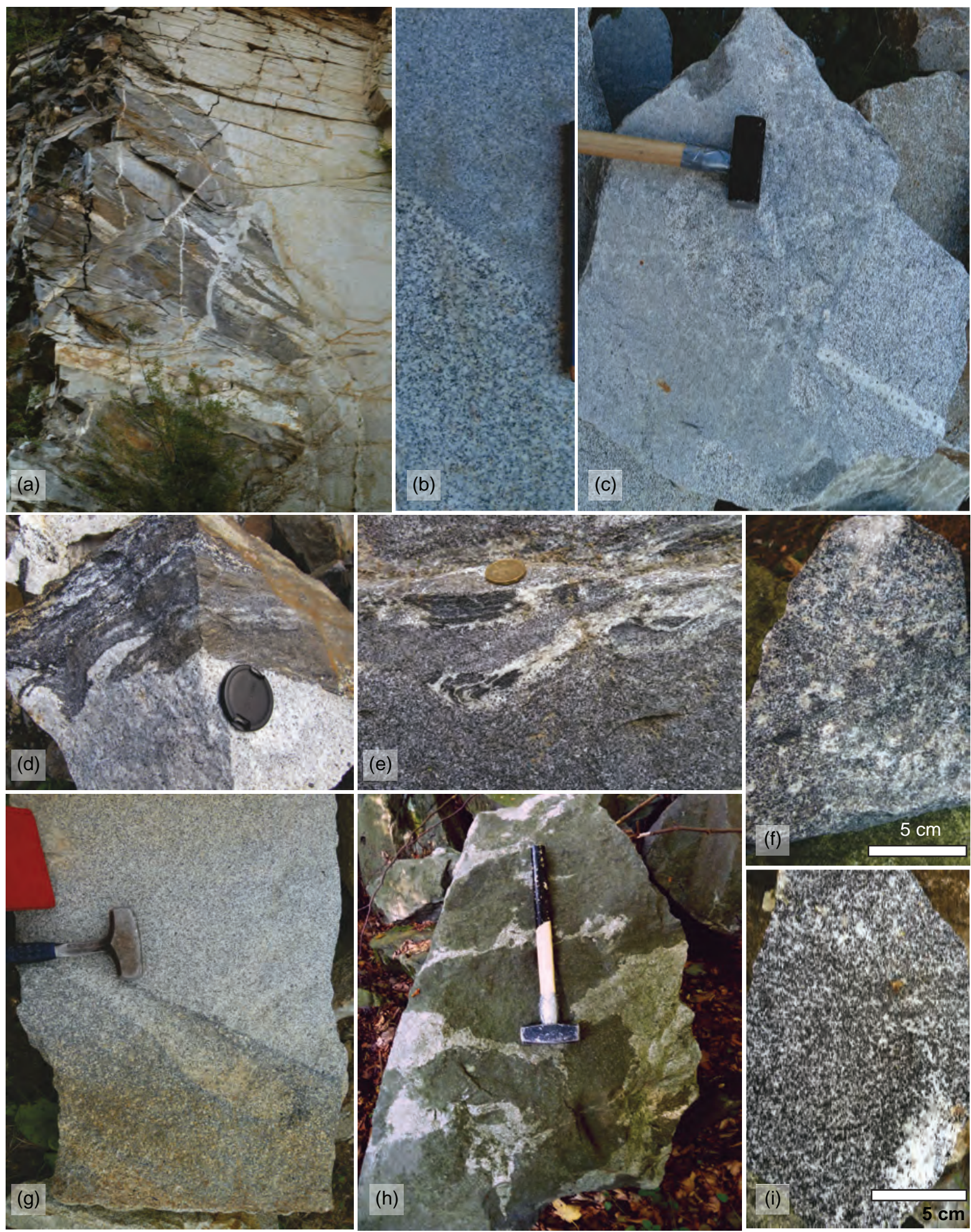

Fig. 3 - Selected field photographs. a - Strongly net-veined and fragmented metapelitic roof pendant fallen into the biotite granite. Vertical size of the

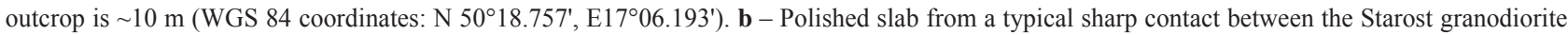
(top) and the biotite granite (bottom). c - Angular fragment of the biotite granite included within the Starost granodiorite (N 50 $18.757^{\prime}$, E1 $\left.17^{\circ} 06.193^{\prime}\right)$. d - Interaction between a metasedimentary xenolith and the biotite granite $\left(\mathrm{N} 50^{\circ} 18.757^{\prime}, \mathrm{E} 17^{\circ} 06.193^{\prime}\right)$. e - Biotite restite found within the quartz monzodiorite $\left(\mathrm{N} 50^{\circ} 18.648^{\prime}, \mathrm{E} 17^{\circ} 7.420^{\prime}\right)$. $\mathbf{f}$ - Hand specimen of an inhomogeneous fine-grained quartz monzodiorite showing a typical sphene-centred ocelli texture $\left(\mathrm{N} 50^{\circ} 15.524^{\prime}, \mathrm{E} 17^{\circ} 08.810^{\prime}\right)$. $\mathbf{g}$ - Accumulation of K-feldspar and biotite crystals within the biotite granite $\left(\mathrm{N} 50^{\circ} 18.648^{\prime}, \mathrm{E} 17^{\circ} 7.420^{\prime}\right)$. $\mathbf{h}$ - Mingling textures between the biotite granite and the fine-grained quartz monzodiorite ( $50^{\circ} 17.348^{\prime}$, E17 $\left.12.452^{\prime}\right)$. $\mathbf{i}-$ Hand specimen of a coarse-grained quartz monzodiorite (N 50¹9.917', E1704.917'). 
K-feldspar (5-20), plagioclase (40-45), biotite (20-25) and amphibole (10-20). Pyroxene relics enclosed in plagioclase were described by Scharff (1920). Accessory minerals include ilmenite, sphene, apatite, zircon, allanite and secondary chlorite, epidote and sericite. In our dataset, only three magnesio-hornblendes from the quartz monzodiorite ZU-6 were in textural equilibrium with the matrix and fall in the calibration range of the geothermobarometer by Ridolfi and Renzulli (2012). Calculated P-T conditions are $758 \pm 22^{\circ} \mathrm{C}$ and $100 \pm 11$ MPa (Electronic Supplementary Material 3).

Mingling features between fine-grained quartz monzodiorite and biotite granite are common, including lobate, liquid-liquid contacts, felsic pipes as well as load casts and flame structures (e.g., Wiebe and Collins 1998) (Fig. 3h). Restitic biotite-rich enclaves forming elongated trains within the coarse grained quartz monzodiorite, itself included in biotite granite, have been observed (Fig. 3e).

\subsection{Xenoliths}

Numerous country-rock xenoliths or even larger roof pendants (up to several tens of meters in size) are present in the pluton underscoring the importance of stoping at final stages of the granitic magma emplacement. Migmatitic biotite-sillimanite gneiss from the Devonian Desná paraautochthon was identified among the country-rock xenoliths. Restitic metapelite (Fig. 3d) with garnet-bearing melt patches occurs either as big septa or sub-horizontal screens. Calc-silicate rocks, with $\mathrm{cm}$-scale garnets and pyroxenes, are probably derived from the Branná Group marbles. Amphibolite, partially recrystallized, showing striking modal and textural similarities with the dark granodiorite, is found within the biotite granite. Metasedimentary staurolite-bearing xenoliths $(<1 \mathrm{~cm})$ are present in isolated bodies of quartz monzodiorite.

\section{Geochronology}

Three samples were dated (all taken from active or just recently abandoned quarries): a quartz monzodiorite (sample ZU-6; WGS84 coordinates: N50 19.917 ', $\left.\mathrm{E} 17^{\circ} 04.917^{\prime}\right)$, a biotite granite (ZU-3; N50 $17.890^{\prime}$, $\left.\mathrm{E} 17^{\circ} 05.789^{\prime}\right)$ and a Starost granodiorite (ZU-17; $\left.\mathrm{N} 50^{\circ} 18.757^{\prime}, \mathrm{E} 17^{\circ} 06.193^{\prime}\right)$.

In quartz monzodiorite $\mathbf{Z U}-\mathbf{6}$, zircon grains are up to $0.5 \mathrm{~mm}$ long with a mean size of $100-250 \mu \mathrm{m}$. They are elongated with an aspect ratio of 1:20 and sometimes have skeletal habits. In cathodoluminescence (CL) images, zircons show a patchy zoning, sometimes flame-like with frequent inclusions forming straight lines along the long axis of the grain (Fig. 4a). Special care was taken to avoid inclusions and cracks and only homogenous parts of zircon grains were used for the analysis. From ZU-6, 21 spots located in CL-bright parts of 17 zircon grains yielded $\mathrm{U}-\mathrm{Pb}$ concordia age of $292 \pm 4 \mathrm{Ma}(2 \sigma$; Fig. 4b). Ten spots in CL-dark parts of eight zircon grains revealed a discordance of the $\mathrm{U}-\mathrm{Pb}$ isotopic system but yield a similar mean ${ }^{206} \mathrm{~Pb} /{ }^{238} \mathrm{U}$ age of $290 \pm 4 \mathrm{Ma}(2 \sigma$; MSWD =1).

The CL images of zircons from the biotite granite ZU-3 show clearly magmatic oscillatory zoning and, sometimes, conspicuous bright rounded inherited cores (Fig. 4c). From ZU-3, seven spots in seven different zircon grains exhibiting a magmatic zoning yielded $\mathrm{U}-\mathrm{Pb}$ concordia age of $291 \pm 5 \mathrm{Ma}$ in the Tera and Wasserburg

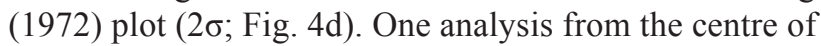
an oscillatory-zoned zircon gave a concordant ${ }^{206} \mathrm{~Pb} /{ }^{238} \mathrm{U}$ age of $299 \pm 3.2$ Ma. Five discordant analyses, together with this latter 299 Ma spot, fall on the same line in the Tera and Wasserburg (1972) plot, with a lower intercept of the concordia curve at $299 \pm 5 \mathrm{Ma}(\mathrm{MSWD}=0.65)$. A rounded inherited core yielded a ${ }^{206} \mathrm{~Pb} /{ }^{238} \mathrm{U}$ age of $513 \pm 9$ Ma (Electronic Supplementary Material 2)

Zircons from the Starost granodiorite ZU-17 have euhedral prismatic shapes, with an aspect ratio of $1: 5$ and pinkish colour. Several grains are sub-rounded and have low aspect ratios of $1: 2$. Typical length is between 75 and $150 \mu \mathrm{m}$. In CL images, zircon crystals show a very regular oscillatory zoning disrupted by angular fragments. Dissolution-recrystallization features blurring the previous oscillatory pattern are common (Fig. 4e). The $\mathrm{U}-\mathrm{Pb}$ dating revealed two distinct populations, the first composed of six spots in six different zircon grains, with a mean ${ }^{206} \mathrm{~Pb} /{ }^{238} \mathrm{U}$ age of $388 \pm 7 \mathrm{Ma}(95 \%$ conf.; MSWD $=2$; Fig. $4 \mathrm{f}$ ) and the second consisting of eight spots in seven grains, with a mean ${ }^{206} \mathrm{~Pb} / 238 \mathrm{U}$ age of $298 \pm 5 \mathrm{Ma}$ ( $95 \%$ conf.; MSWD = 1.1; Fig. 4f).

\section{Whole-rock geochemistry}

\subsection{Major elements}

The new dataset of ten samples (Tabs 1-2) was supplemented by 41 unpublished trace- and major-element analyses from the database of the Czech Geological Survey (Čadková et al. 1985; Žáček et al. 2004b, 2005b; Pecina et al. 2006) and four by Zachovalová et al. (2002) which are reported in Electronic Supplementary Material 4.

A wide range of rocks are represented in the pluton, ranging from 54 to $75 \mathrm{wt}$. $\% \mathrm{SiO}_{2}$. Using the $\mathrm{P}-\mathrm{Q}$ multicationic plot (Debon and Le Fort 1983), samples can be classified between monzodiorite and granite endmembers, with transitional compositions corresponding to quartz monzodiorite, granodiorite and 'adamellite' 

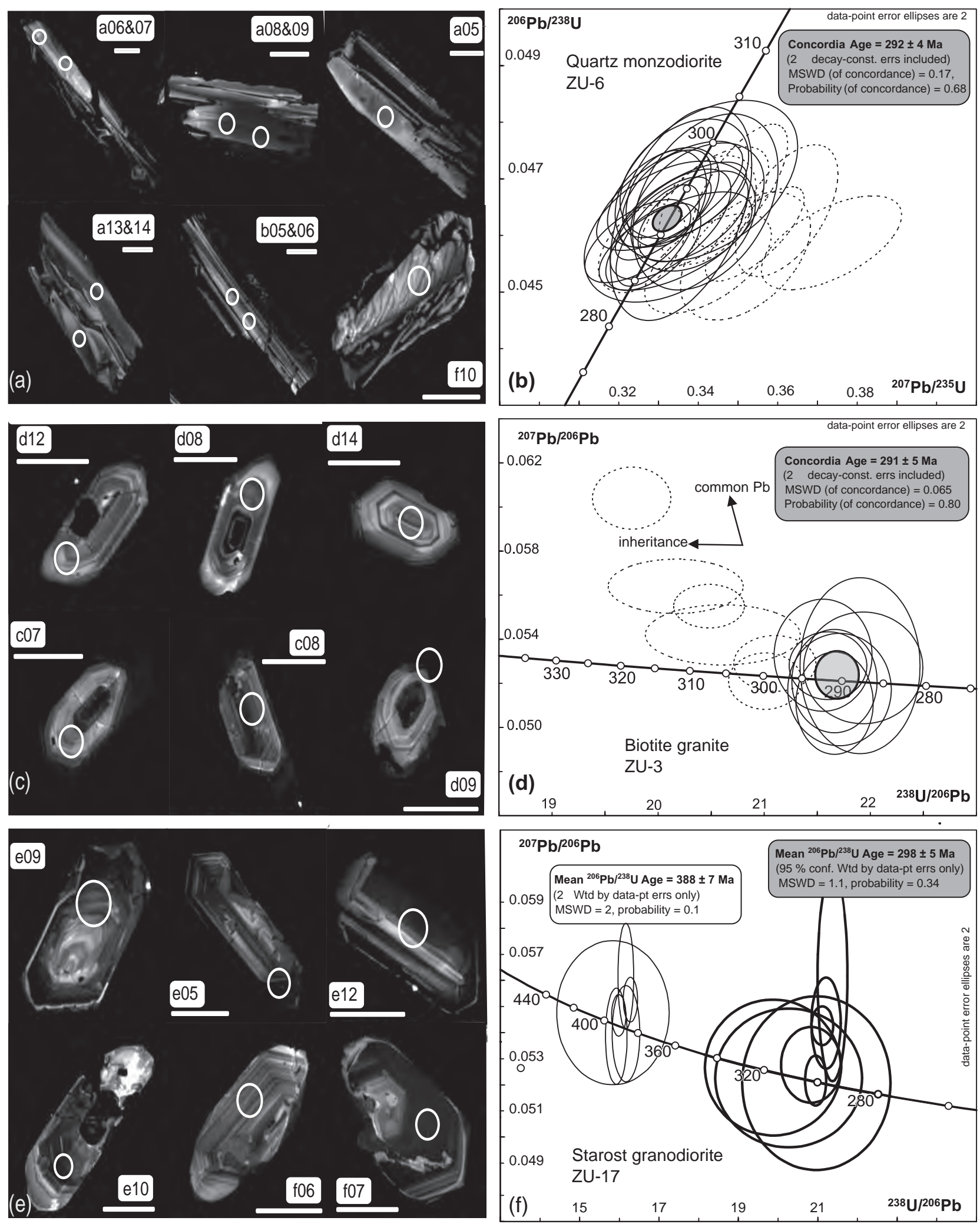

Fig. 4 - Representative CL images of dated zircon grains (a, c, e), together with the resulting Concordia (b) and Tera-Wasserburg (d, f) diagrams. Scale bar is always $100 \mu \mathrm{m}$; white circles depict the location of analytical spots. The corresponding isotopic ratios are given in Electronic Supplementary Material 2. All data are shown at $2 \sigma$ confidence level, discordant data are plotted in dashed lines. The arrow toward common-lead composition in (d-f) is calculated following the model of Stacey and Kramers (1975). a-b - Quartz monzodiorite (ZU-6). c-d - Biotite granite (ZU-3). e-f - Starost granodiorite (ZU-1). In figure e, the upper row represents $\sim 298$ Ma grains and below are $\sim 388$ Ma grains. 
Tab. 1 Whole-rock major-element data from the studied samples (wt. \%)

\begin{tabular}{|c|c|c|c|c|c|c|c|c|c|c|}
\hline Sample & $\mathrm{Zu}-8$ & $\mathrm{Zu}-11$ & $\mathrm{Zu}-14$ & $\mathrm{Zu}-3$ & $\mathrm{Zu}-17$ & $\mathrm{Zu}-7$ & $\mathrm{Zu}-5$ & Zu-9.1 & $\mathrm{Zu}-6$ & $\mathrm{Zu}-10$ \\
\hline Rock type & $\begin{array}{l}\text { Biotite } \\
\text { granite }\end{array}$ & $\begin{array}{l}\text { Biotite } \\
\text { granite }\end{array}$ & $\begin{array}{l}\text { Biotite } \\
\text { granite }\end{array}$ & $\begin{array}{l}\text { Biotite } \\
\text { granite }\end{array}$ & $\begin{array}{l}\text { Starost } \\
\text { grano- } \\
\text { diorite }\end{array}$ & $\begin{array}{l}\text { Dark } \\
\text { grano- } \\
\text { diorite }\end{array}$ & $\begin{array}{l}\text { Dark } \\
\text { grano- } \\
\text { diorite }\end{array}$ & $\begin{array}{c}\text { Quartz } \\
\text { monzo- } \\
\text { diorite }\end{array}$ & $\begin{array}{c}\text { Quartz } \\
\text { monzo- } \\
\text { diorite }\end{array}$ & $\begin{array}{l}\text { Quartz } \\
\text { monzo- } \\
\text { diorite }\end{array}$ \\
\hline $\mathrm{x}$ & $\mathrm{N} 50^{\circ} 18.648$ & $\mathrm{~N} 50^{\circ} 18.152$ & $\mathrm{~N} 50^{\circ} 19.285$ & $\mathrm{~N} 50^{\circ} 17.890$ & $\mathrm{~N} 50^{\circ} 18.757$ & $\mathrm{~N} 50^{\circ} 19.917$ & $\mathrm{~N} 50^{\circ} 16.590$ & $\mathrm{~N} 50^{\circ} 15.477$ & $\mathrm{~N} 50^{\circ} 19.917$ & $\mathrm{~N} 50^{\circ} 17.348$ \\
\hline $\mathrm{y}$ & $\mathrm{E} 17^{\circ} 7.420$ & $\mathrm{E} 17^{\circ} 11.301$ & $\mathrm{E} 17^{\circ} 10.183$ & E17⒌789 & $\mathrm{E} 17^{\circ} 06.193$ & $\mathrm{E} 17^{\circ} 4.917$ & $\mathrm{E} 17^{\circ} 7.860$ & $\mathrm{E} 17^{\circ} 8.343$ & E17⒋917 & $\mathrm{E} 17^{\circ} 12.452$ \\
\hline $\mathrm{SiO}_{2}$ & 73.00 & 73.70 & 74.50 & 74.80 & 71.00 & 63.70 & 65.00 & 54.20 & 54.60 & 56.50 \\
\hline $\mathrm{TiO}_{2}$ & 0.30 & 0.20 & 0.19 & 0.19 & 0.29 & 1.11 & 0.88 & 1.96 & 1.75 & 1.73 \\
\hline $\mathrm{Al}_{2} \mathrm{O}_{3}$ & 13.50 & 13.90 & 13.30 & 13.10 & 14.10 & 15.50 & 15.20 & 15.60 & 15.40 & 15.30 \\
\hline $\mathrm{FeO}$ & 1.74 & 1.44 & 1.44 & 1.21 & 1.81 & 4.33 & 3.60 & 7.39 & 7.32 & 7.02 \\
\hline $\mathrm{Fe}_{2} \mathrm{O}_{3}$ & 0.36 & 0.09 & 0.06 & 0.25 & 0.56 & 1.69 & 1.33 & 2.00 & 1.58 & 1.94 \\
\hline $\mathrm{MnO}$ & 0.04 & 0.03 & 0.03 & 0.03 & 0.06 & 0.10 & 0.07 & 0.16 & 0.17 & 0.16 \\
\hline $\mathrm{MgO}$ & 0.46 & 0.41 & 0.27 & 0.25 & 0.70 & 1.51 & 1.78 & 3.30 & 4.09 & 2.98 \\
\hline $\mathrm{CaO}$ & 1.73 & 1.59 & 1.18 & 1.17 & 1.99 & 4.15 & 3.32 & 7.01 & 7.15 & 6.20 \\
\hline $\mathrm{Na}_{2} \mathrm{O}$ & 3.28 & 3.52 & 3.20 & 3.41 & 3.75 & 3.71 & 3.74 & 3.76 & 3.35 & 3.43 \\
\hline $\mathrm{K}_{2} \mathrm{O}$ & 4.30 & 4.06 & 4.65 & 4.61 & 4.37 & 2.75 & 3.38 & 2.17 & 2.34 & 2.33 \\
\hline $\mathrm{P}_{2} \mathrm{O}_{5}$ & 0.06 & 0.07 & 0.05 & 0.05 & 0.08 & 0.23 & 0.31 & 0.83 & 0.74 & 0.70 \\
\hline $\mathrm{F}$ & 0.06 & 0.06 & 0.07 & 0.06 & 0.06 & 0.07 & 0.08 & 0.13 & 0.12 & 0.13 \\
\hline $\mathrm{CO}_{2}$ & 0.09 & $<0.01$ & 0.07 & 0.05 & $<0.01$ & 0.06 & 0.02 & 0.01 & 0.07 & 0.06 \\
\hline LOI & 0.56 & 0.59 & 0.60 & 0.55 & 0.58 & 1.00 & 0.90 & 1.20 & 1.29 & 1.44 \\
\hline $\mathrm{H}_{2} \mathrm{O}^{-}$ & $<0.05$ & $<0.05$ & $<0.05$ & $<0.05$ & 0.12 & $<0.05$ & 0.06 & 0.05 & 0.11 & 0.06 \\
\hline Total & 99.60 & 99.70 & 99.60 & 99.70 & 99.40 & 99.90 & 99.70 & 99.80 & 100.00 & 99.90 \\
\hline $\mathrm{K}_{2} \mathrm{O} / \mathrm{Na}_{2} \mathrm{O}$ & 1.31 & 1.15 & 1.45 & 1.35 & 1.17 & 0.74 & 0.90 & 0.58 & 0.70 & 0.68 \\
\hline $\mathrm{CaO} / \mathrm{Na}_{2} \mathrm{O}$ & 0.53 & 0.45 & 0.37 & 0.34 & 0.53 & 1.12 & 0.89 & 1.86 & 2.13 & 1.81 \\
\hline mg\# & 28.5 & 32.5 & 24.4 & 23.8 & 35.1 & 31.5 & 39.8 & 39.0 & 45.5 & 37.7 \\
\hline $\mathrm{A} / \mathrm{NK}$ & 1.35 & 1.37 & 1.29 & 1.20 & 1.29 & 1.70 & 1.55 & 1.83 & 1.90 & 1.87 \\
\hline $\mathrm{A} / \mathrm{CNK}$ & 1.02 & 1.06 & 1.07 & 1.03 & 0.97 & 0.93 & 0.96 & 0.73 & 0.73 & 0.79 \\
\hline $\mathrm{Al}_{2} \mathrm{O}_{3} / \mathrm{TiO}_{2}$ & 45.1 & 69.6 & 69.8 & 68.9 & 48.5 & 14.0 & 17.3 & 8.0 & 8.8 & 8.8 \\
\hline
\end{tabular}

(a disused term according to the current IUGS classification scheme) (Fig. 5a). The B-A plot (Debon and Le Fort 1983) (Fig. 5b) can be used to express the contents of mafic components $\mathrm{Fe}, \mathrm{Mg}$ and $\mathrm{Ti}(=\mathrm{B})$, their relation to the aluminium balance (A) and thus the characteristic mineral assemblage. Samples define a trend from the hornblende > biotite metaluminous field for quartz monzodiorite and granodiorites, to the weakly peraluminous biotite field for granite. If expressed by the Shand's index $\mathrm{A} / \mathrm{CNK}$ [molar $\left.\mathrm{Al}_{2} \mathrm{O}_{3} /\left(\mathrm{CaO}+\mathrm{Na}_{2} \mathrm{O}+\mathrm{K}_{2} \mathrm{O}\right)\right]$, quartz monzodiorite $(\mathrm{A} / \mathrm{CNK}=0.73-0.79)$ and granodiorites $(\mathrm{A} / \mathrm{CNK}=0.93-0.97)$ are metaluminous whereas biotite granites are slightly peraluminous $(\mathrm{A} / \mathrm{CNK}=1.02-1.07)$.

The pluton is composed of sub-alkaline rocks, as demonstrated by the TAS diagram (Irvine and Baragar 1971; Cox et al. 1979) (Fig. 5c), defining a calc-alkaline series in the AFM diagram (Irvine and Baragar 1971) (Fig. 5d) and following a high-K calc-alkaline trend in $\mathrm{SiO}_{2}$ vs. $\mathrm{K}_{2} \mathrm{O}$ plot (Peccerillo and Taylor 1976) (Fig. 5e). The mg numbers [molar $100 \times \mathrm{MgO} /(\mathrm{MgO}+\mathrm{FeOt})]$ correlate negatively with $\mathrm{SiO}_{2}$, from $0.44-0.38$ in the intermediate samples down to 0.24 in the most acidic rocks (Fig. 6).

Harker diagrams display negative linear correlations of $\mathrm{SiO}_{2}$ with $\mathrm{TiO}_{2}, \mathrm{FeO}_{t}, \mathrm{MgO}, \mathrm{CaO}$ while $\mathrm{P}_{2} \mathrm{O}_{5}$ is slightly inflexed (Fig. 6). The $\mathrm{Al}_{2} \mathrm{O}_{3}, \mathrm{Na}_{2} \mathrm{O}$ and $\mathrm{K}_{2} \mathrm{O}$ show poor correlations with marked inflexion at $\sim 70 \% \mathrm{SiO}_{2}$. So- dium prevails over potassium in quartz monzodiorite $\left(\mathrm{K}_{2} \mathrm{O} / \mathrm{Na}_{2} \mathrm{O}=0.58-0.70\right.$ by weight $)$, whereas this ratio ranges from 1.2 to 1.5 in granites. The $\mathrm{CaO} / \mathrm{Na}_{2} \mathrm{O}$ ratios show a negative linear correlation with $\mathrm{SiO}_{2}$, varying between 2.1 in the quartz monzodiorite and 0.34 in the most acidic granite.

\subsection{Trace elements}

The trace-element signatures of the studied samples are presented as Normal Mid-Ocean Ridge Basalts (NMORB) normalized (Sun and McDonough 1989) spiderplots (Fig. 7a). The quartz monzodiorites show strong enrichment in the Large Ion Lithophile Elements (LILE; e.g., $\mathrm{Rb}_{\mathrm{N}}$ up to $150 \times \mathrm{NMORB}$ ) whilst they are rather poor in Heavy Rare Earth Elements (HREE; $\mathrm{Lu}_{\mathrm{N}}$ $\sim 2 \times$ NMORB). On this steep pattern are superimposed weak negative anomalies in $\mathrm{U}, \mathrm{Nb}, \mathrm{Sr}, \mathrm{Ti}$ and a positive anomaly in $\mathrm{Pb}$. High contents of High-Field-Strength Elements (HFSE: e.g., $\mathrm{Nb}$ and $\mathrm{Zr}$ ) but also $\mathrm{Y}$ are typical. Biotite granites show larger enrichments in LILE $\left(\mathrm{Rb}_{\mathrm{N}}\right.$ $=300-450 \times \mathrm{NMORB})$ but much lower HFSE contents and deeper $\mathrm{Nb}, \mathrm{Sr}, \mathrm{P}$, and Ti troughs as well as a more conspicuous $\mathrm{Pb}$ peak relative to quartz monzodiorites. The Starost granodiorite displays a pattern very similar to that observed for the biotite granite while the dark 
Tab. 2 Whole-rock trace-element data from the studied samples (ppm)

\begin{tabular}{|c|c|c|c|c|c|c|c|c|c|c|}
\hline Rock type & $\begin{array}{c}\mathrm{Zu}-8 \\
\text { Biotite } \\
\text { granite }\end{array}$ & $\begin{array}{l}\mathrm{Zu}-11 \\
\text { Biotite } \\
\text { granite }\end{array}$ & $\begin{array}{l}\mathrm{Zu}-14 \\
\text { Biotite } \\
\text { granite }\end{array}$ & $\begin{array}{c}\mathrm{Zu}-3 \\
\text { Biotite } \\
\text { granite }\end{array}$ & $\begin{array}{l}\text { Zu-17 } \\
\text { Starost } \\
\text { grano- } \\
\text { diorite }\end{array}$ & $\begin{array}{c}\text { Zu-7 } \\
\text { Dark } \\
\text { grano- } \\
\text { diorite }\end{array}$ & $\begin{array}{c}\text { Zu-5 } \\
\text { Dark } \\
\text { grano- } \\
\text { diorite }\end{array}$ & $\begin{array}{c}\text { Zu-9.1 } \\
\text { Quartz } \\
\text { monzo- } \\
\text { diorite }\end{array}$ & $\begin{array}{c}\text { Zu-6 } \\
\text { Quartz } \\
\text { monzo- } \\
\text { diorite }\end{array}$ & $\begin{array}{l}\text { Zu-10 } \\
\text { Quartz } \\
\text { monzo- } \\
\text { diorite }\end{array}$ \\
\hline $\mathrm{Ba}$ & 887 & 1030 & 550 & 493 & 719 & 930 & 1060 & 811 & 710 & 729 \\
\hline $\mathrm{Rb}$ & 177 & 197 & 229 & 252 & 117 & 113 & 120 & 79.4 & 62.5 & 95.0 \\
\hline $\mathrm{Sr}$ & 149 & 186 & 95 & 84 & 225 & 293 & 321 & 334 & 350 & 309 \\
\hline $\mathrm{Zr}$ & 203 & 132 & 140 & 180 & 207 & 339 & 336 & 515 & 415 & 495 \\
\hline $\mathrm{Nb}$ & 17.4 & 14.1 & 18.8 & 21.4 & 12.9 & 26.5 & 25.7 & 48.9 & 45.8 & 48.4 \\
\hline $\mathrm{Ni}$ & $<3$ & 3 & $<3$ & $<3$ & $<3$ & 4 & 4 & 7 & 10 & 7 \\
\hline $\mathrm{Co}$ & 5 & 3 & 3 & 3 & 6 & 20 & 16 & 36 & 40 & 35 \\
\hline $\mathrm{Zn}$ & 48 & 41 & 48 & 42 & 64 & 88 & 76 & 130 & 120 & 123 \\
\hline Cs & 3.1 & 5.9 & 5.4 & 6.5 & 4.4 & 3.5 & 3.4 & $<0.7$ & 0.8 & 2.2 \\
\hline $\mathrm{Ta}$ & 1.56 & 1.34 & 1.87 & 2.46 & 1.02 & 2.07 & 1.71 & 2.55 & 2.83 & 2.82 \\
\hline Hf & 6.58 & 4.32 & 5.31 & 6.28 & 6.45 & 9.5 & 9.53 & 13.3 & 11.0 & 12.8 \\
\hline $\mathrm{Sc}$ & 4.87 & 3.99 & 4.20 & 4.05 & 6.41 & 15.4 & 10.7 & 19.2 & 18.7 & 19.3 \\
\hline $\mathrm{Cr}$ & 9 & 10 & 10 & 10 & 12 & 9 & 28 & 30 & 95 & 30 \\
\hline $\mathrm{V}$ & 22.1 & 15.6 & 10.9 & 9.4 & 30.5 & 117 & 58.9 & 139 & 126 & 140 \\
\hline Th & 21.1 & 24.1 & 28.2 & 25.5 & 13.0 & 13.2 & 11.1 & 10.2 & 9.32 & 13.7 \\
\hline $\mathrm{U}$ & 5.55 & 5.67 & 5.90 & 3.47 & 1.30 & 3.42 & 2.22 & 1.24 & 1.35 & 2.04 \\
\hline $\mathrm{Pb}$ & 22.2 & 22.5 & 27.9 & 25.1 & 15.1 & 15.2 & 16.7 & 11.0 & 12.1 & 13.1 \\
\hline $\mathrm{Y}$ & 27.7 & 32.3 & 30.9 & 35.0 & 24.1 & 45.4 & 38.3 & 58.8 & 50.3 & 56.7 \\
\hline $\mathrm{La}$ & 56.8 & 49.8 & 48.1 & 40.5 & 35.2 & 51.8 & 60.4 & 70.9 & 70.2 & 85.9 \\
\hline $\mathrm{Ce}$ & 114 & 96.7 & 101 & 87.8 & 78.5 & 109 & 120 & 160 & 154 & 183 \\
\hline $\operatorname{Pr}$ & 12.3 & 10.3 & 11.3 & 9.9 & 7.95 & 12.8 & 14.2 & 19.6 & 18.4 & 21.2 \\
\hline $\mathrm{Nd}$ & 43.4 & 36.5 & 41.2 & 36.5 & 29.2 & 50.6 & 55.2 & 80.0 & 73.7 & 82.9 \\
\hline $\mathrm{Sm}$ & 7.54 & 6.36 & 8.02 & 7.44 & 5.30 & 10.04 & 9.76 & 15.5 & 13.8 & 15.2 \\
\hline $\mathrm{Eu}$ & 0.80 & 0.69 & 0.58 & 0.54 & 0.91 & 1.83 & 1.74 & 3.09 & 2.92 & 3.03 \\
\hline $\mathrm{Gd}$ & 5.30 & 4.60 & 6.40 & 6.20 & 4.00 & 8.70 & 8.00 & 13.4 & 11.7 & 12.8 \\
\hline Dy & 4.99 & 5.46 & 5.67 & 6.18 & 3.98 & 8.18 & 6.88 & 11.2 & 9.64 & 10.8 \\
\hline Ho & 1.08 & 1.040 & 1.21 & 1.36 & 0.92 & 1.80 & 1.51 & 2.35 & 2.04 & 2.32 \\
\hline $\mathrm{Er}$ & 2.83 & 2.70 & 3.17 & 3.58 & 2.48 & 4.65 & 3.95 & 6.06 & 5.38 & 5.90 \\
\hline $\mathrm{Tm}$ & 0.39 & 0.391 & 0.44 & 0.51 & 0.35 & 0.64 & 0.55 & 0.81 & 0.72 & 0.80 \\
\hline $\mathrm{Yb}$ & 2.55 & 3.15 & 3.06 & 3.53 & 2.54 & 4.28 & 3.81 & 5.29 & 4.78 & 5.31 \\
\hline $\mathrm{Lu}$ & 0.42 & 0.51 & 0.50 & 0.56 & 0.45 & 0.69 & 0.63 & 0.92 & 0.83 & 0.89 \\
\hline$\overline{\mathrm{Eu}} / \mathrm{Eu}^{*}$ & 0.38 & 0.39 & 0.25 & 0.24 & 0.60 & 0.60 & 0.60 & 0.66 & 0.70 & 0.67 \\
\hline $\mathrm{La}_{\mathrm{N}} / \mathrm{Yb}_{\mathrm{N}}$ & 15.01 & 21.31 & 10.60 & 7.72 & 9.33 & 8.17 & 10.71 & 9.04 & 9.89 & 10.92 \\
\hline $\mathrm{La}_{\mathrm{N}} / \mathrm{Sm}_{\mathrm{N}}$ & 4.74 & 4.93 & 3.77 & 3.42 & 4.18 & 3.25 & 3.89 & 2.88 & 3.20 & 3.55 \\
\hline$\Sigma \mathrm{REE}$ & 254 & 214 & 232 & 206 & 173 & 267 & 288 & 392 & 371 & 433 \\
\hline
\end{tabular}

granodiorite has incompatible trace-element concentrations intermediate between the quartz monzodiorite and the biotite granite.

For the quartz monzodiorite, the REE patterns normalized to chondrite (Boynton 1984) exhibit a fairly low degree of LREE/HREE enrichment $\left(\mathrm{La}_{\mathrm{N}} / \mathrm{Yb}_{\mathrm{N}}=\right.$ 9-11; $\left.\mathrm{La}_{\mathrm{N}} / \mathrm{Sm}_{\mathrm{N}}=2.8-3.6\right)$ and a significant negative Eu anomaly $\left(\mathrm{Eu} / \mathrm{Eu}^{*}=0.65-0.70\right)$ (Fig. 7b). The total REE concentration is high ( $\Sigma$ REE $\sim 400 \mathrm{ppm})$. The dark granodiorite and the Starost granodiorite REE patterns are sub-parallel to that of the quartz monzodiorite, with a significantly lower total REE concentrations ( $\Sigma$ REE $287 \mathrm{ppm}$ in the dark granodiorite and $\sim 172 \mathrm{ppm}$ in the Starost granodiorite) and a slightly more pronounced negative Eu anomaly $\left(\mathrm{Eu} / \mathrm{Eu}^{*} \sim 0.60\right)$. The biotite granite is characterized by a low to moderate degree of LREE/
HREE enrichment $\left(\mathrm{La}_{\mathrm{N}} / \mathrm{Yb}_{\mathrm{N}}=6-15 ; \mathrm{La}_{\mathrm{N}} / \mathrm{Sm}_{\mathrm{N}}=3.4-5.5\right)$ and a deep Eu anomaly $\left(\mathrm{Eu} / \mathrm{Eu}^{*}=0.24-0.39\right)$ compared to granodiorites and the quartz monzodiorite. The sample ZU-2 has a distinctly higher LREE content $\left(\mathrm{La}_{\mathrm{N}}=260 \times\right.$ chondrite) but its HREE distribution resembles that of the other biotite granites.

In granitic rocks, the LILE are hosted by major phases such as biotite, K-feldspar and plagioclase. In course of fractional crystallization, especially $\mathrm{Ba}, \mathrm{Rb}$ and $\mathrm{Sr}$ provide important constraints on the cumulus composition due to their contrasting behaviour. Barium and $\mathrm{Rb}$ are incorporated preferentially into K-bearing phases, biotite and $\mathrm{K}$-feldspar, while $\mathrm{Sr}$ is partitioned mainly into both feldspars, given the low modal amounts of apatite.

The $\mathrm{SiO}_{2}$ vs. Ba plot (Fig. 8a) has a bell shape indicating an independent position of the more basic rocks 

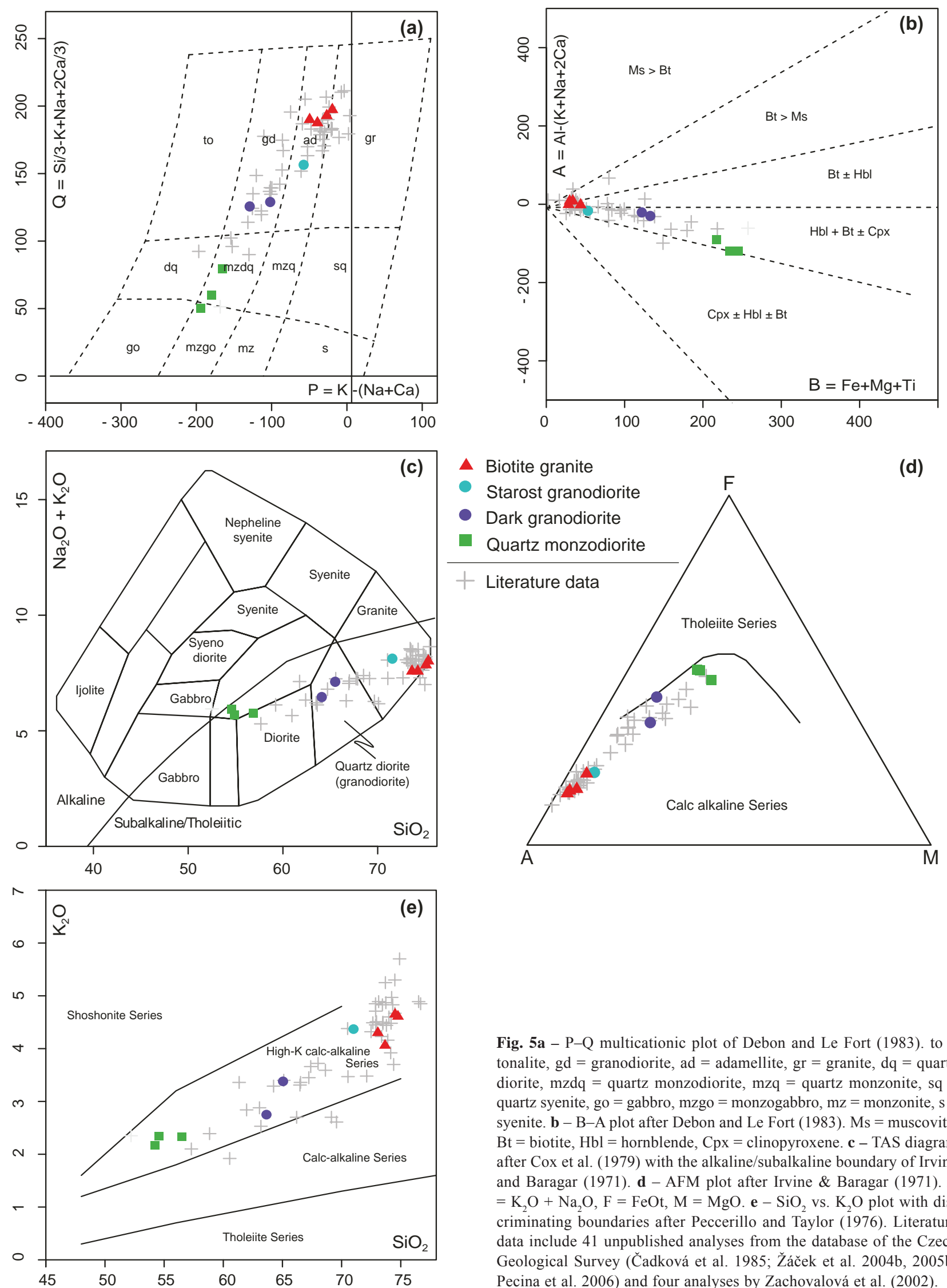

Fig. 5a - P-Q multicationic plot of Debon and Le Fort (1983). to = tonalite, $\mathrm{gd}=$ granodiorite, $\mathrm{ad}=$ adamellite, $\mathrm{gr}=$ granite, $\mathrm{dq}=$ quartz diorite, $\mathrm{mzdq}=$ quartz monzodiorite, $\mathrm{mzq}=$ quartz monzonite, $\mathrm{sq}=$ quartz syenite, go $=$ gabbro, $\mathrm{mzgo}=$ monzogabbro, $\mathrm{mz}=$ monzonite, $\mathrm{s}=$ syenite. $\mathbf{b}-\mathrm{B}-\mathrm{A}$ plot after Debon and Le Fort (1983). Ms = muscovite, $\mathrm{Bt}=$ biotite, $\mathrm{Hbl}=$ hornblende, $\mathrm{Cpx}=$ clinopyroxene. $\mathbf{c}-\mathrm{TAS}$ diagram after Cox et al. (1979) with the alkaline/subalkaline boundary of Irvine and Baragar (1971). d - AFM plot after Irvine \& Baragar (1971). A $=\mathrm{K}_{2} \mathrm{O}+\mathrm{Na}_{2} \mathrm{O}, \mathrm{F}=\mathrm{FeOt}, \mathrm{M}=\mathrm{MgO}$. e $-\mathrm{SiO}_{2}$ vs. $\mathrm{K}_{2} \mathrm{O}$ plot with discriminating boundaries after Peccerillo and Taylor (1976). Literature data include 41 unpublished analyses from the database of the Czech Geological Survey (Čadková et al. 1985; Žáček et al. 2004b, 2005b; Pecina et al. 2006) and four analyses by Zachovalová et al. (2002). 

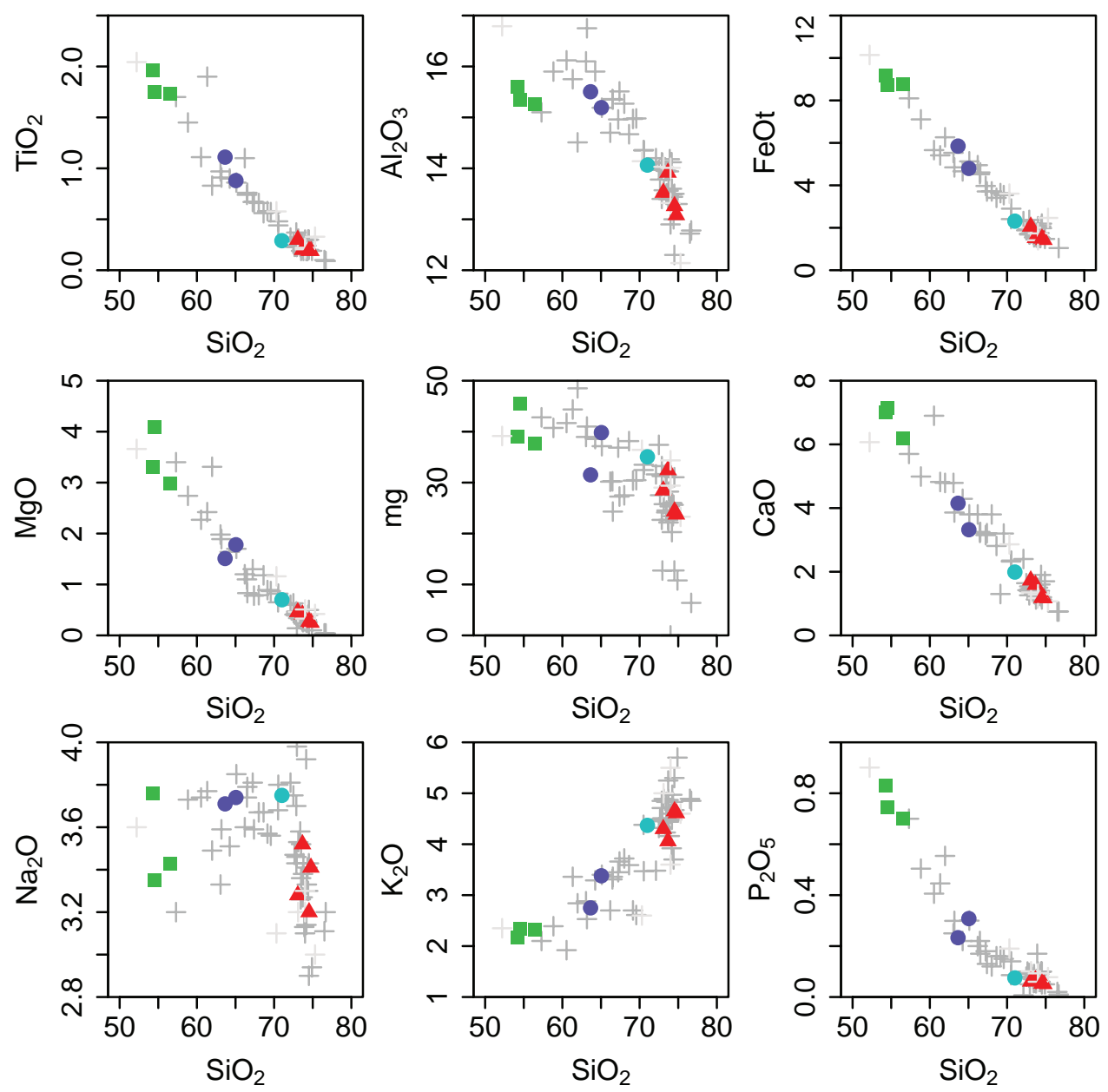

Fig. 6 Harker diagrams (in wt. \%). Symbols are as in Fig. 5.

within the suite. Indeed, the $\mathrm{Ba}-\mathrm{Sr}$ plot in logarithmic coordinates shows the presence of two distinct but broadly parallel linear trends, the first represented by granitic and the second by granodioritic samples (Fig. 8b). The first trend is compatible with up to $15 \%$ fractional crystallization of a K-feldspar > plagioclase assemblage. The log $\mathrm{Ba}$ vs. $\log \mathrm{Rb}$ plot underscores the independent position of the quartz monzodiorite and confirms that $\mathrm{K}$-feldspar with minor plagioclase fractional crystallization is a plausible model to explain the variation in the granites (Fig. 8c).

In the tectonic discriminant diagrams proposed by Pearce et al. (1984), quartz monzodiorites plot in the within-plate field whereas granites fall systematically in the volcanic-arc field or straddle the boundary between the two fields (Fig. 9a-b). In a ternary diagram of Hf$\mathrm{Rb} / 30-3 \times \mathrm{Ta}$ (Harris et al. 1986), most granites fall in the late or post-collisional calc-alkaline field which is distinguished from volcanic-arc granites by higher Ta/ Hf ratios and from syn-collisional granites by lower $\mathrm{Rb}$ (Fig. 9c). The Starost granodiorite falls in the volcanic-arc granite field along with one analysis of the biotite granite. In the ternary $\mathrm{Th}-\mathrm{Hf} / 3-\mathrm{Nb} / 16$ tectonic

discriminant diagram for basic rocks (Wood 1980), the quartz monzodiorites form a linear array in the field of calc-alkaline basalts. This distribution reflects high, but variable, Th contents compared to MORB and withinplate tholeiites (Fig. 9d) rather than the presence of $\mathrm{Nb}$ depletion characteristic of igneous-arc settings (see also the lack of pronounced $\mathrm{Nb}$ anomaly in NMORBnormalized spiderplot).

\subsection{Zircon saturation temperatures}

The temperature of a magma from which accessory minerals such as apatite, monazite or zircon crystallized may be estimated from experimentally calibrated saturation models (e.g., Hanchar and Watson 2003). The negative $\mathrm{SiO}_{2}-\mathrm{Zr}$ correlation in the whole suite suggests early zircon saturation (Fig. 10a). Zircon saturation temperature $\left(\mathrm{T}_{\mathrm{Zn}}\right)$ calculations following Watson and Harrison (1983) yield broadly similar results for the quartz monzodiorite $\left(776-814^{\circ} \mathrm{C}\right)$, the Starost granodiorite $\left(798^{\circ} \mathrm{C}\right)$ and the biotite granite $\left(773-806^{\circ} \mathrm{C}\right)$ (Fig. 10b). The dark granodiorite has a distinctly higher $\mathrm{T}_{\mathrm{Zrn}}$ of $825-830^{\circ} \mathrm{C}$. 

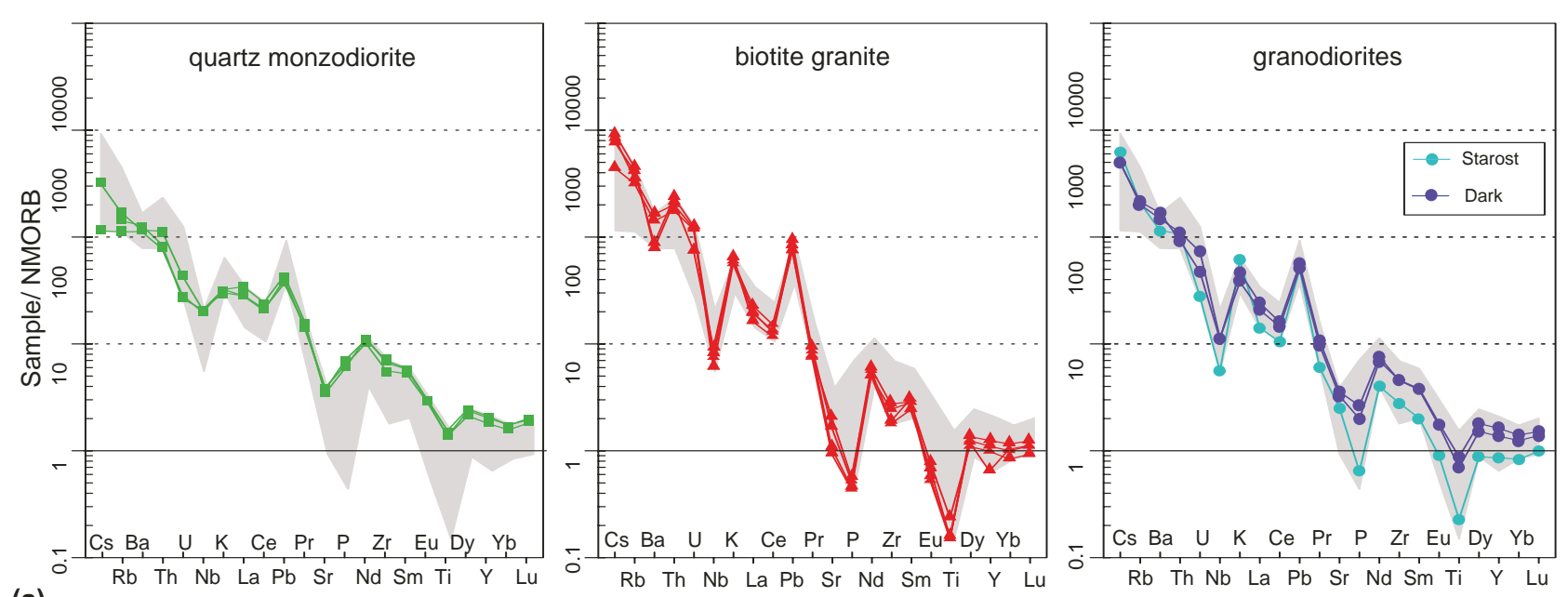

(a)

(b)
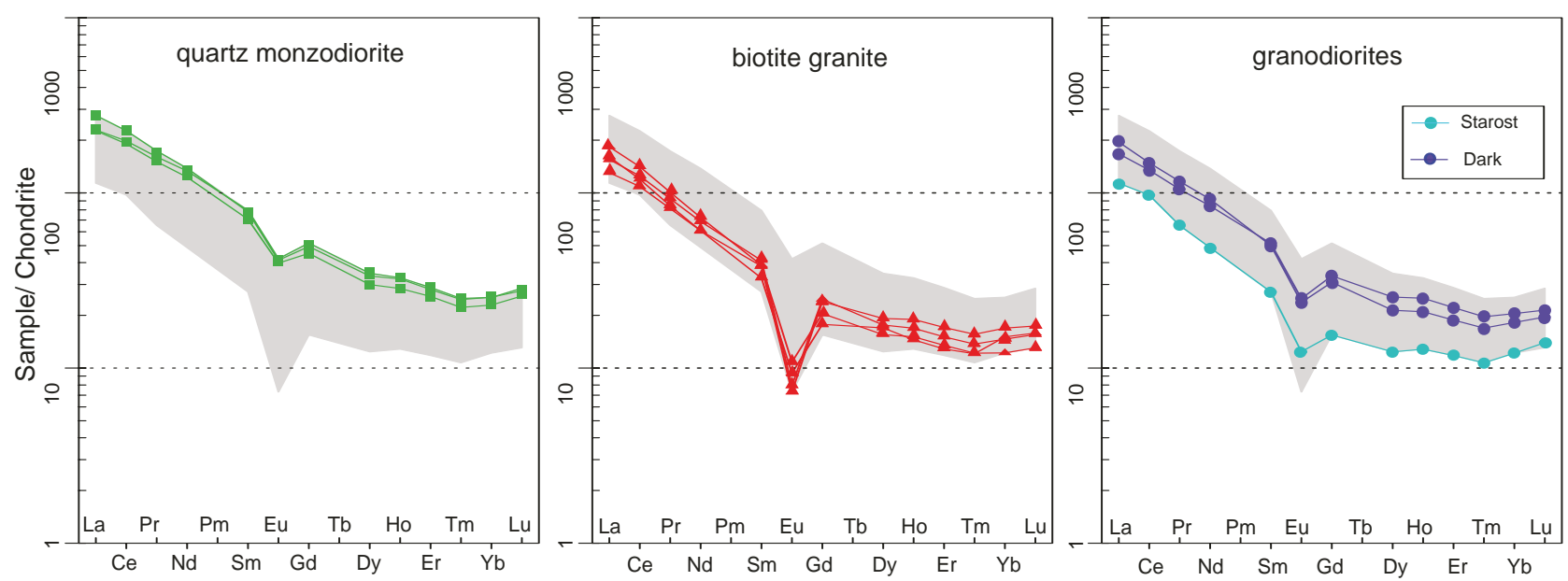

Fig. 7a - Spider plots normalized to NMORB (Sun and McDonough 1989). b - Rare Earth Element patterns normalized to chondrite (Boynton 1984). The dataset is divided into three groups based on major-element geochemistry: quartz monzodiorite, biotite granite and granodiorites. The grey shaded area represents the overall variability of the dataset.

The $\mathrm{T}_{\mathrm{Zrn}}$ have proven to be rather robust to the presence of minor inheritance (Janoušek 2006). Thus, the $\mathrm{T}_{\mathrm{Zrn}}\left(773-806^{\circ} \mathrm{C}\right)$ from the biotite granite is probably a good estimate of the liquidus magma temperature. For the quartz monzodiorite, the skeletal shapes, the high elongation ratios of zircons and the presence of axial melt trails support a rather late and rapid growth (Corfu et al. 2003). Given the absence of inheritance, $\mathrm{T}_{\mathrm{Zrn}}$ only provide a lower constraint on the liquidus temperature of quartz monzodiorite magma which was in excess of $800^{\circ} \mathrm{C}$.

\section{4. $\mathrm{Sr}-\mathrm{Nd}$ isotopes}

Whole-rock $\mathrm{Sr}-\mathrm{Nd}$ isotopic compositions of nine selected samples are presented in Tab. 3. The initial $\varepsilon_{\mathrm{Nd}}$ values were age-corrected to $292 \mathrm{Ma}$, assuming the newly de- termined $\mathrm{U}-\mathrm{Pb}$ zircon age. The isotopic data of quartz monzodiorite show only minor variations, with slightly negative $\varepsilon^{292}$ of -2.7 to -3.0 and rather radiogenic strontium $\left({ }^{87} \mathrm{Sr} /{ }^{86} \mathrm{Sr}_{292}=0.7073-0.7076\right)$. Neodymium isotopic compositions for granites are more scattered but still similar to those of quartz monzodiorite $\left(\varepsilon^{292}{ }_{\mathrm{Nd}}=\right.$ -2.0 to -3.6$)$; $\mathrm{Sr}$ is less radiogenic $\left({ }^{87} \mathrm{Sr} /{ }^{86} \mathrm{Sr}_{292}=0.7051\right.$ to 0.7059$)$. Dark granodiorite shows the lowest $\varepsilon^{292}$ Nd $(-4.2)$ and highest ${ }^{87} \mathrm{Sr} /{ }^{86} \mathrm{Sr}_{292}(0.7076)$, similar to that of quartz monzodiorite (Fig. 11a). The Starost granodiorite has the most primitive characteristics $\left(\varepsilon_{\mathrm{Nd}}^{292}=+0.6\right.$ and $\left.{ }^{87} \mathrm{Sr} /{ }^{86} \mathrm{Sr}_{292}=0.7045\right)$. The two-stage Depleted Mantle $\mathrm{Nd}$ model ages (Liew and Hofmann 1988) for granite and quartz monzodiorite samples show a similar crustal residence (1.18-1.30 Ga) (Tab. 3; Fig. 11b), whereas the Starost granodiorite yields a slightly younger model age of $0.97 \mathrm{Ga}$. 

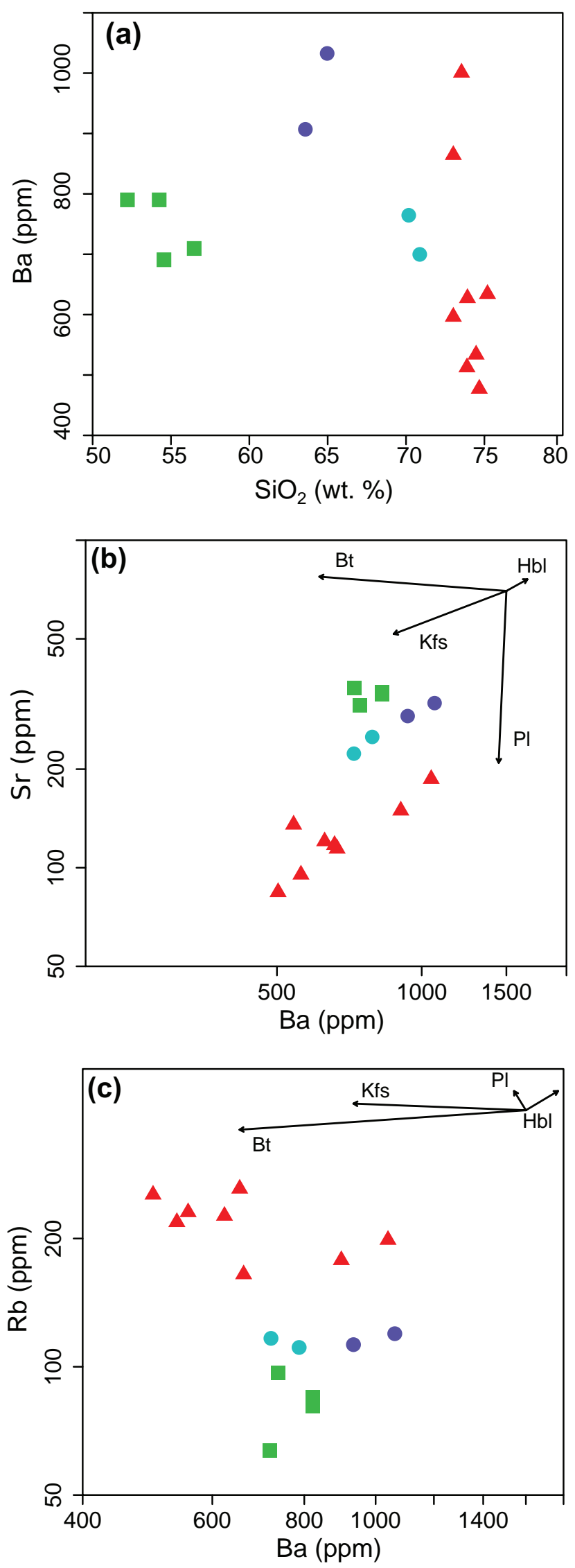

\section{Discussion}

\subsection{Timing of emplacement}

Timing the assembly of composite plutons may be challenging, especially when using LA-ICP-MS or SHRIMP methods (e.g., Kryza et al. 2014b). The most reliable data to constrain the final emplacement age in such cases come from the intermediate lithologies which underwent rapid cooling and zircon crystallization, although care must be taken to avoid zircon crystals re-equilibrated with late magmatic fluids (e.g., Kusiak et al. 2009). In the Žulová Composite Pluton the final emplacement of the quartz monzodiorite is constrained by the new $\mathrm{U}-\mathrm{Pb}$ age at $292 \pm 4 \mathrm{Ma}$ and that of biotite granite at $291 \pm 5$ Ma. These ages overlap within error, in accord with the field evidence indicating mafic melt injection into still not fully solidified granitic mush. Besides, the Starost granodiorite displays two age components: the older, $388 \pm 7$ Ma population that is most likely inherited from the source, and the younger, $298 \pm 5 \mathrm{Ma}$, probably magmatic. From the field relationships, the Starost granodiorite is slightly younger than the biotite granite suggesting (i) incorporation of antecrysts (Miller et al. 2007) during incremental building of the magma chamber over several My or (ii) the presence of zircons that have crystallized in the partially molten source, before melt extraction. Six spots displaying older apparent ${ }^{206} \mathrm{~Pb} /{ }^{238} \mathrm{U}$ ages retrieved from the biotite granite (dashed ellipses in Fig. 4f) also point to unresolved inheritance.

Even though the precision of our zircon age data from the Starost granodiorite is not high enough to unequivocally prove a protracted magmatic activity, we suggest that the magmatic episode, from source melting to final emplacement, could have spanned some 5-10 My with a well constrained emplacement episode at $\sim 292 \mathrm{Ma}$. This scenario is in broad agreement with ${ }^{40} \mathrm{Ar}-{ }^{39} \mathrm{Ar}$ dating of a Žulová granodiorite sampled along the south-western margin of the pluton (Maluski et al. 1995). The similarity of ${ }^{40} \mathrm{Ar}-{ }^{39} \mathrm{Ar}$ ages obtained from amphibole $(292 \pm 3 \mathrm{Ma})$ and biotite $(290 \pm 3 \mathrm{Ma})$, which have different closure temperatures, indicate rapid cooling and thus may be close to the emplacement age.

Fig. 8 - Binary plots portraying variation of selected trace elements. $\mathbf{a}-\mathrm{SiO}_{2}-\mathrm{Ba} ; \mathbf{b}-\log \mathrm{Ba}-\log \mathrm{Sr} ; \mathbf{c}-\log \mathrm{Ba}-\log \mathrm{Rb}$. In b-c, arrows represent effects of $10 \%$ fractional crystallization of the individual rock-forming minerals. Partition coefficients for plagioclase $(\mathrm{Pl})$ were obtained following Blundy and Shimizu (1991), assuming An $=20$ and $\mathrm{T}=750^{\circ} \mathrm{C}$. Partition coefficients for biotite $(\mathrm{Bt})$ were taken from Icenhower and London (1996) and those for K-feldspar (Kfs) and hornblende (Hbl) from Hanson and Langmuir (1978). The dataset was supplemented by six unpublished trace-element analyses (Laurent 2013; reported in Electronic Supplementary Material 4). Symbols are as in Fig. 5. 
Tab. $3 \mathrm{Sr}-\mathrm{Nd}$ isotopic data, measured and age-corrected to $292 \mathrm{Ma}$

\begin{tabular}{llcccccccccc}
\hline Sample & Rock type & ${ }^{87} \mathrm{Sr} /{ }^{86} \mathrm{Sr}$ & $\pm 2 \mathrm{SE}$ & ${ }^{87} \mathrm{Rb} /{ }^{86} \mathrm{Sr}$ & ${ }^{143} \mathrm{Nd} /{ }^{144} \mathrm{Nd}$ & $\pm 2 \mathrm{SE}$ & ${ }^{147} \mathrm{Sm} /{ }^{144} \mathrm{Nd}$ & ${ }^{87} \mathrm{Sr} /{ }^{86} \mathrm{Sr}_{292}$ & $\varepsilon^{292} \mathrm{Nd}$ & $\mathrm{T}_{\mathrm{DM}}$ & $\mathrm{T}_{\mathrm{DM}} 2 \mathrm{st}$. \\
\hline Zu-3 & Bt granite & 0.741286 & 0.000010 & 8.71 & 0.512340 & 0.000016 & 0.1232 & 0.70510 & -3.1 & 1.29 & 1.26 \\
Zu-8 & Bt granite & 0.719709 & 0.000010 & 3.43 & 0.512358 & 0.000019 & 0.1050 & 0.70544 & -2.0 & 1.06 & 1.18 \\
Zu-11 & Bt granite & 0.717975 & 0.000010 & 3.07 & 0.512280 & 0.000029 & 0.1052 & 0.70522 & -3.6 & 1.17 & 1.30 \\
Zu-14 & Bt granite & 0.734993 & 0.000015 & 6.99 & 0.512351 & 0.000016 & 0.1177 & 0.70593 & -2.7 & 1.20 & 1.23 \\
Zu-17 & Starost gd & 0.710728 & 0.000012 & 1.50 & 0.512503 & 0.000011 & 0.1097 & 0.70450 & +0.6 & 0.90 & 0.97 \\
Zu-7 & Dark gd & 0.712190 & 0.000010 & 1.11 & 0.512274 & 0.000018 & 0.1201 & 0.70756 & -4.2 & 1.35 & 1.35 \\
Zu-6 & Q mnzd & 0.709761 & 0.000011 & 0.52 & 0.512326 & 0.000019 & 0.1129 & 0.70761 & -3.0 & 1.18 & 1.25 \\
Zu-10 & Q mnzd & 0.711066 & 0.000012 & 0.89 & 0.512318 & 0.000017 & 0.1109 & 0.70737 & -3.0 & 1.17 & 1.25 \\
Zu-9.1 & Q mnzd & 0.710182 & 0.000012 & 0.69 & 0.512349 & 0.000020 & 0.1172 & 0.70732 & -2.7 & 1.20 & 1.23 \\
\hline
\end{tabular}

Starost $\mathrm{gd}=$ Starost granodiorite, $\mathrm{Bt}$ granite $=$ biotite granite, $\mathrm{Q}$ mnzd $=$ quartz monzodiorite.

$\mathrm{T}_{\mathrm{DM}}=$ single-stage Depleted Mantle Nd model age after Jacobsen and Wasserburg (1980), $\mathrm{T}_{\mathrm{DM}} 2$ st. = two-stage Depleted Mantle Nd model age after Liew and Hofmann (1988) - both in Ga.
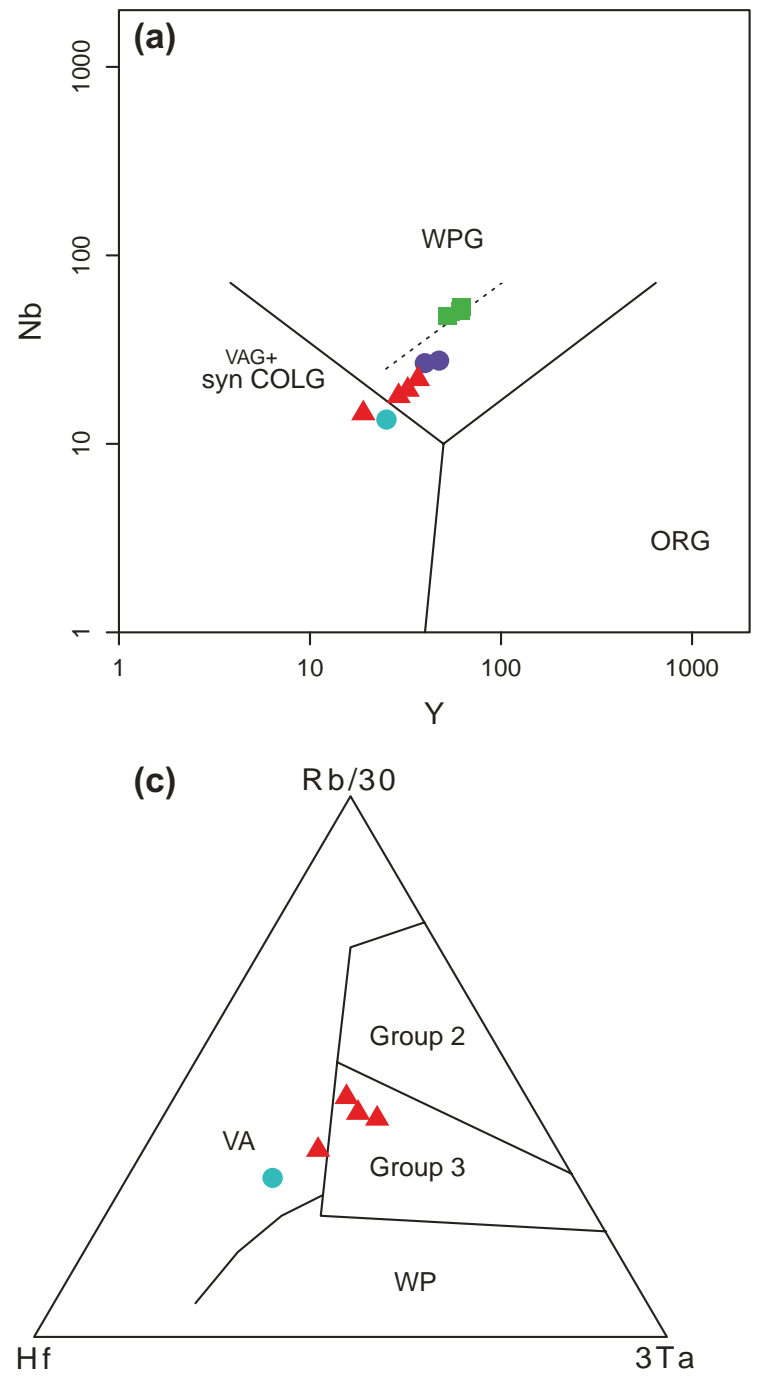
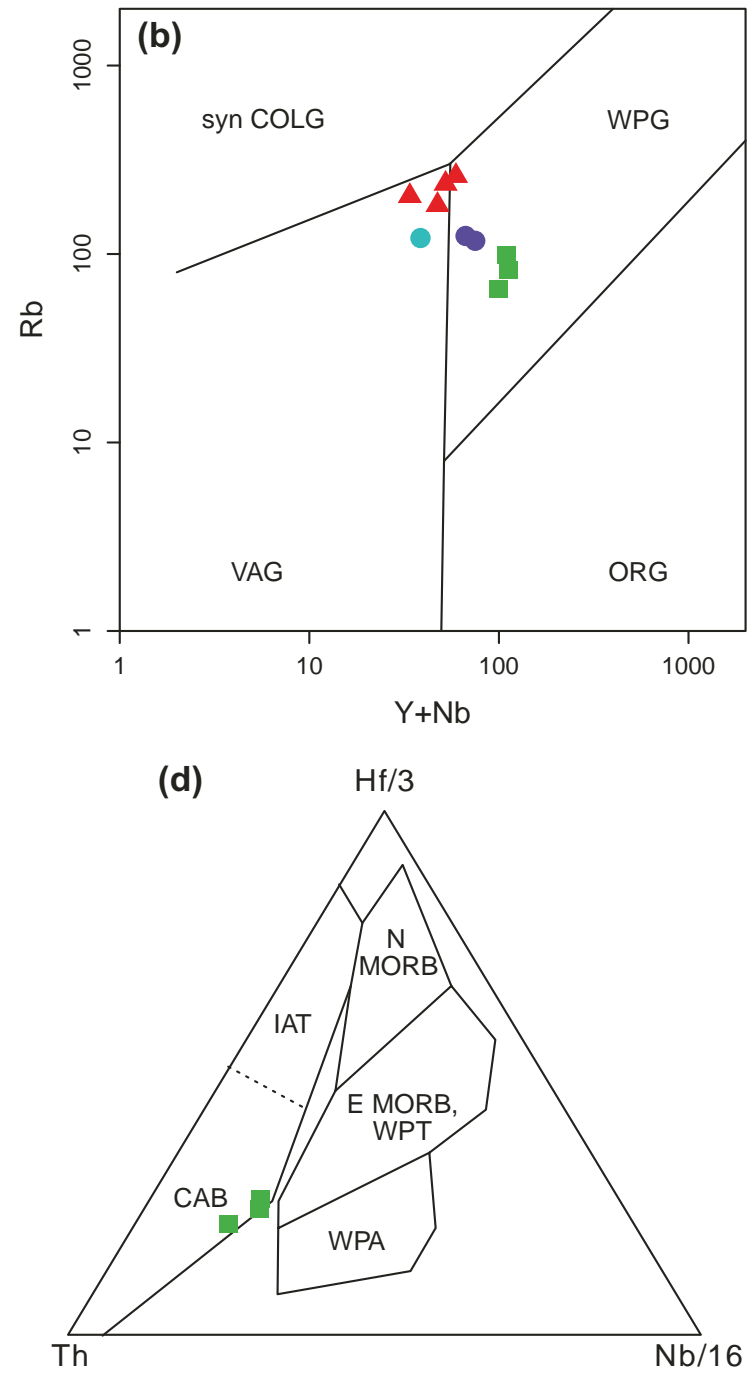

Fig. 9a-b Tectonic discriminant diagrams $\mathrm{Y}$ vs. $\mathrm{Nb}$ and $\mathrm{Y}+\mathrm{Nb}$ vs. Rb of Pearce et al. (1984). Syn-COLG $=$ Syn-Collisional Granite, WPG $=$ Within-Plate Granite, ORG = Ocean Ridge Granite, VAG = Volcanic Arc Granite. $\mathbf{c}-$ Ternary tectonic discriminant diagram Hf-Rb/30-3×Ta after Harris et al. (1986). Only samples with $\mathrm{SiO}_{2}>65$ wt. \% are plotted. Group 2: syn-collisional peraluminous intrusions, Group 3: late or post-collisional calc-alkaline intrusions, $\mathrm{VA}=$ Volcanic Arc, $\mathrm{WP}=$ Within Plate. $\mathbf{d}-$ Tectonic discriminant diagram Th-Hf/3-Nb/16 for basic rocks of Wood (1980). Only samples with $\mathrm{SiO}_{2}<57$ wt. $\%$ are shown. IAT $=$ Island-arc Tholeiite, $\mathrm{CAB}=$ Calc-Alkaline Basalt, NMORB $=$ Normal-type Mid Ocean Ridge Basalt, EMORB = Enriched-type Mid Ocean Ridge Basalt, WPT = Within-Plate Tholeiite, WPA = Within-Plate Alkaline basalts Symbols are as in Fig. 5. 

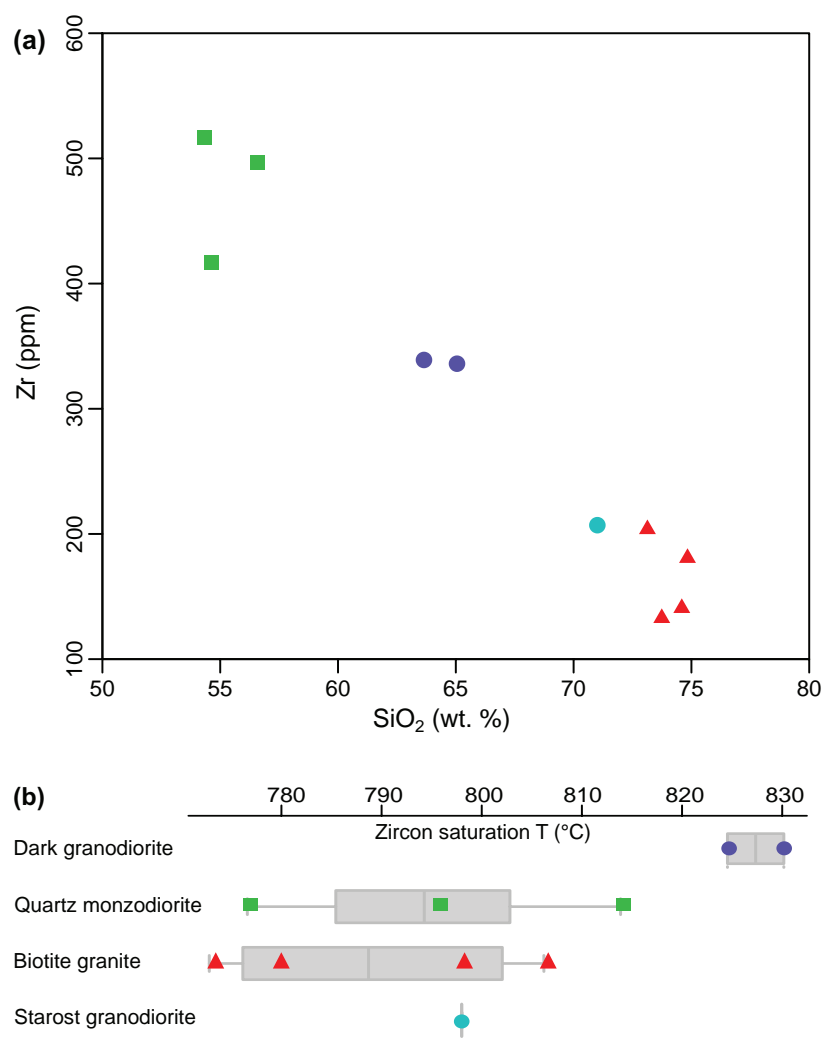

Fig. 10a - Binary plot of $\mathrm{SiO}_{2}$ (wt. \%) versus $\mathrm{Zr}$ (ppm). b - Boxplot of zircon saturation temperatures after Watson and Harrison (1983) presented for each rock-type.

\subsection{Magma evolution}

The local differences in feldspar abundance and grainsize within the biotite granite may be explained by fractional crystallization. Modelling of $15 \%$ fractional crystallization in $\mathrm{Ba}-\mathrm{Sr}$ and $\mathrm{Ba}-\mathrm{Rb}$ diagrams (Fig. 8b-c) documents a dominant influence of K-feldspar and minor role for plagioclase. This is in line with a sharp drop in $\mathrm{Al}_{2} \mathrm{O}_{3}$ and $\mathrm{Na}_{2} \mathrm{O}$ within the biotite granite, as well as the progressively deepening negative Eu anomaly. Strontium in the biotite granite $\left({ }^{87} \mathrm{Sr}^{86} \mathrm{Sr}_{292}=0.7051-0.7059\right)$ has a distinctly more primitive signature than in the quartz monzodiorite (0.7073-0.7076), even though the $\mathrm{Nd}$ isotopic compositions are similar. The evolution of the felsic suite (i.e. biotite granite and Starost granodiorite) by wall-rock assimilation and fractional crystallization of a an intermediate or mafic melt parental to the quartz monzodiorite is therefore unlikely as it would require a hypothetic $\mathrm{SiO}_{2}$-rich contaminant with $\mathrm{Sr}$ isotopic composition close to, or even less evolved than, the Bulk Earth $\left({ }^{87} \mathrm{Sr} /{ }^{86} \mathrm{Sr}_{292} \sim 0.7042\right)$.

Within the pluton, the coexistence of mafic and felsic magmas is demonstrated by liquid-liquid contacts, mixing microtextures and similar U-Pb ages. However, large-scale hybridization between granitic and quartz monzodioritic magmas cannot account for the observed
$\mathrm{Sr}$ and $\mathrm{Nd}$ isotopic variation (Fig. 11a). Indeed, the putative intermediate mixing products, i.e. the Starost and dark granodiorites, have the least and the most evolved isotopic signatures, respectively. It may well be that mafic to intermediate melts were present in limited volumes and had isotopic compositions too similar to influence significantly that of the granitic melt. Therefore, the different rocks making up the Žulová Composite Pluton should have originated from distinct and/or heterogeneous sources.

\subsection{Source of the parental magmas}

\subsubsection{Quartz monzodiorite}

During the post-collisional to post-orogenic period, both mantle and crustal sources are thought to be involved in magma genesis (Bonin et al. 1998; Bonin 2004). A mixed crustal-mantle origin for the quartz monzodiorite is supported by (i) the initial $\mathrm{Sr}$ isotopic ratios of 0.707 and $\varepsilon^{292}$ Nd values of -2.7 to -3.0 which are outside of typical mantle composition and (ii) disequilibrium textures in minerals (Electronic Supplementary Material 3). The relative contribution of mantle- and crustally-derived material may be assessed from the trace-element composition.

In NMORB normalized spiderplots, the quartz monzodiorite pattern is characterized by LILE enrichment, weak negative $\mathrm{Sr}$ anomaly and rather high contents of HFSE (especially $\mathrm{Zr}, \mathrm{Nb}$ and $\mathrm{Ti}$ ) and $\mathrm{Y}$. The high contents of LILE, $\mathrm{Th}$ and $\mathrm{Pb}$ have been used as a hint for crustal contamination of mafic magmas (Wood 1980). Yet, it is difficult to decipher whether most of the crustal contamination took place during magma ascent (e.g., De Paolo 1981; Kemp et al. 2007; Pietranik et al. 2011) or whether these are inherent characteristics of the mantle itself (e.g., Janoušek et al. 1995; Miller et al. 1999; Conticelli et al. 2009; Willbold and Stracke 2010). In the latter case, this could reflect the interaction with deeply subducted continental crust, metasomatism by fluids/ small-scale melts derived from oceanic slab above an older subduction zone or even metasomatism of an ancient lithospheric mantle. Besides, the rather high HFSE contents are typical of within-plate settings (Pearce et al. 1984) and are interpreted to reflect a primitive (or even enriched) mantle source. Thus, two hypotheses arise: (i) melting of a mantle enriched in LILE, metasomatized/contaminated probably during the Early Devonian subduction, by heat of the upwelling asthenosphere or (ii) extensive crustal contamination of a basaltic melt, extracted from a primitive mantle source, by the metagranitic and metasedimentary basement of the Desná Dome - a suitable contaminant from the $\mathrm{Nd}$ isotopic perspective (Fig. 11b). 

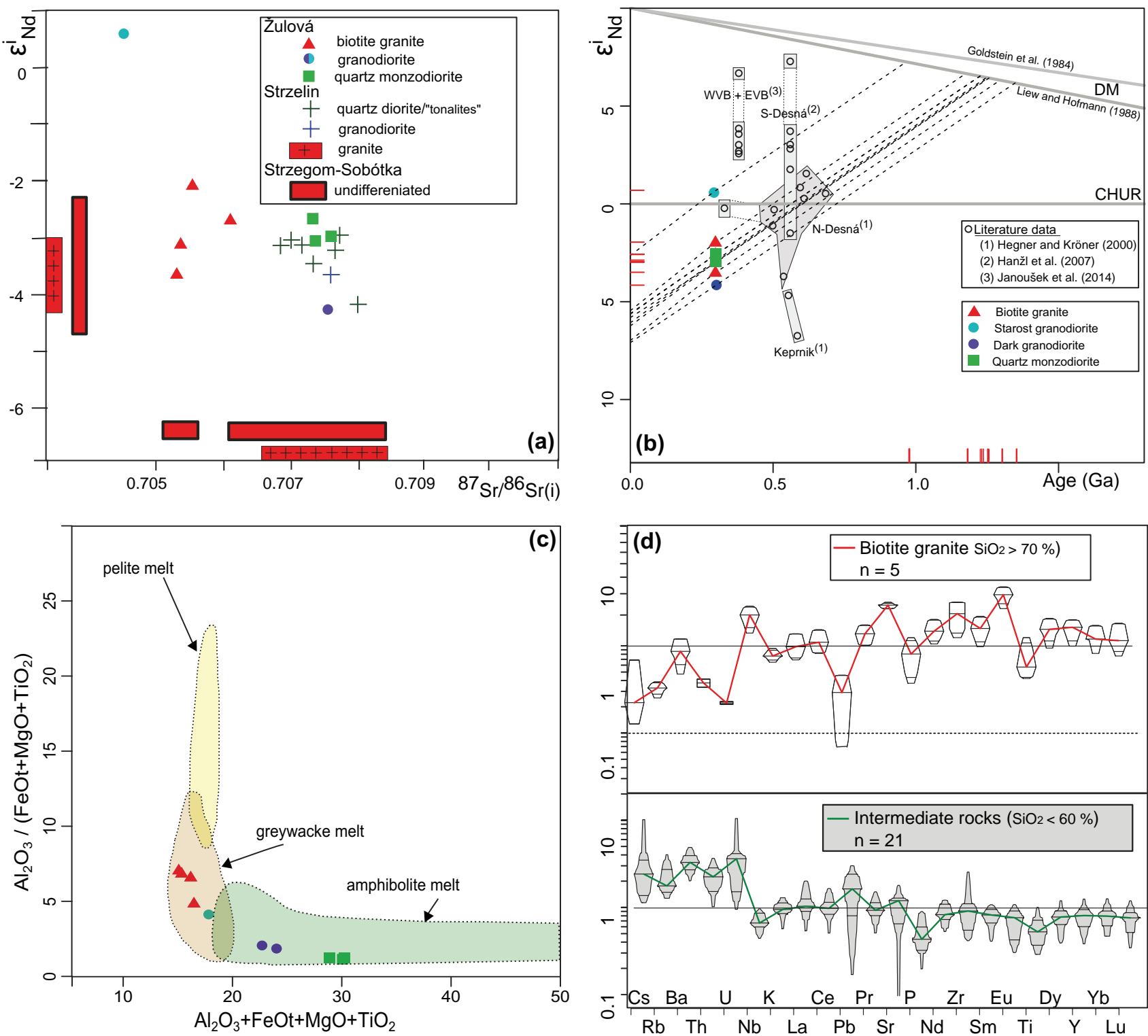

Fig. 11a - Comparison of $\mathrm{Sr}-\mathrm{Nd}$ isotopic data in initial ${ }^{87} \mathrm{Sr} /{ }^{86} \mathrm{Sr}$ versus $\varepsilon_{\mathrm{Nd}}$ diagram: Žulová Composite Pluton (this study), Strzelin Massif (Oberc-Dziedzic et al. 1996; Pietranik and Waight 2008; Pietranik and Koepke 2009; Oberc-Dziedzic et al. 2010) and Strzegom-Sobótka Massif (Pin et al. 1989; Domańska-Siuda 2007). Data from Oberc-Dziedzic et al. (1996, 2010) were age-corrected to 300 Ma. b - Two-stage Nd development diagram showing ranges of $\varepsilon^{292}$ values for the studied samples. Depleted-Mantle (DM) evolution lines after Liew and Hofmann (1988) and Goldstein et al. (1984). (1) Literature data for the northern Desná Dome basement (Neoproterozoic-Cambrian orthogneisses, Devonian metasediments; $\mathrm{n}=8)$ and the Keprník Dome gneisses $(\mathrm{n}=2)$ are from Hegner and Kröner (2000). (2) Data from the southern Desná Dome basement $(\mathrm{n}=6)$ are from Hanžl et al. (2007). (3) Data from the metavolcanic units $(n=6)$ [Eastern Volcanic Belt (EVB) and Western volcanic Belt (WVB)] exposed further south as a part of the Desná Dome cover of the Vrbno Group are from Janoušek et al. (2014). c $-\mathrm{Binary}$ plot of $\mathrm{Al}_{2} \mathrm{O}_{3}+\mathrm{FeOt}+\mathrm{MgO}+$ $\mathrm{TiO}_{2}$ versus $\mathrm{Al}_{2} \mathrm{O}_{3} /\left(\mathrm{FeOt}+\mathrm{MgO}+\mathrm{TiO}_{2}\right)$. Outlined are domains occupied by experimental granitic melts obtained by partial melting of metapelites, metagreywackes and amphibolites (experiments of Patiño Douce 1999 as summarized by Jung et al. 2009). d - Spider boxplots portraying the distribution of selected trace-elements of the Strzelin Massif granitoids normalized by the average composition of the Žulová biotite granite (SiO $>70$ wt. \%) and intermediate samples $\left(\mathrm{SiO}_{2}<60 \%\right)$. Normalization values for biotite granite include samples: ZU-3, ZU-8, ZU-11, ZU-14; for intermediate rocks: ZU-6, ZU-9.1, ZU-10. Data from the Strzelin Massif by Pietranik et al. (2006), Pietranik and Waight (2008), Pietranik and Koepke (2009) and Oberc-Dziedzic et al. (2010, 2013).

\subsubsection{Biotite granite and Starost granodiorite}

The biotite granite and the Starost granodiorite show mutually comparable trace-element patterns and $\mathrm{Sr}$ isotopic compositions. The observed negative $\mathrm{Nb}, \mathrm{Ta}, \mathrm{P}$ and $\mathrm{Ti}$ anomalies, associated with a positive $\mathrm{Pb}$ anomaly as well as high $\mathrm{Th} / \mathrm{Ta}$ ratios, are diagnostic of subduction-related materials (Pearce and Peate 1995; Schandl and Gorton 2002). Consequently, for both igneous units, one can assume an arc-related source, depleted in HFSE, which 
should have relatively unradiogenic strontium $\left({ }^{87} \mathrm{Sr} /{ }^{86} \mathrm{Sr}_{292}\right.$ $=0.7045-0.7059$ ) and a low time-integrated $\mathrm{Rb} / \mathrm{Sr}$ ratio.

The predominance of ilmenite over magnetite in the Žulová granitoids (Zachovalová et al. 2002) points to a rather reduced environment which is typical of sedimentary lithologies rich in organic matter (Ishihara 1981; Takagi 2004). Another constraint comes from the $\mathrm{CaO} /$ $\mathrm{Na}_{2} \mathrm{O}$ ratio which is supposed to reflect the plagioclase to clay proportion in the source and can therefore be used to distinguish between pelitic and psammitic parentages (Sylvester 1998). The biotite granite has a mean $\mathrm{CaO} / \mathrm{Na}_{2} \mathrm{O}$ ratio of 0.42 (Tab. 1), supporting a plagioclase-rich source.

Based on a compilation of experimental data, Jung et al. (2009) proposed a diagram to discriminate between possible sources of granitoids. In this diagram (Fig. 11c), the biotite granite falls in the greywacke field while the Starost granodiorite is at the boundary between the greywacke and the amphibolite fields. This is in line with the subaluminous to slightly peraluminous character of the suite and the negative $\mathrm{Eu}$ and $\mathrm{Sr}$ anomalies which favour a plagioclase-rich residue.

The Starost granodiorite contains a reasonable amount of large $(>150 \mu \mathrm{m})$ inherited zircon meaning that the melt was oversaturated with respect to $\mathrm{Zr}$ during anatexis (Miller et al. 2003) and that the source region was probably Zr-rich. The zircons yield a narrow range of concordant ages of $388 \pm 7 \mathrm{Ma}$, with thin overgrowths $(<10 \mu \mathrm{m})$ or even lacking any visible rims (Fig. $4 \mathrm{e}$ lower row). This observation points to a source dominated by Devonian (meta-) volcanic rocks and/or immature metasediments (greywackes) with a considerable volcanic admixture. In contrast, in mature metasedimentary lithologies one would expect to encounter a wider range of inherited age components. One possible protolith for the Starost granodiorite would be fairly radiogenic in $\mathrm{Nd}\left(\varepsilon^{292} \mathrm{Nd}=\right.$ +0.6 ), easy to melt, and volcanic in nature, i.e. most likely Devonian tuffs of the Vrbno Group. The derivation of the Starost granodiorite from a Western Volcanic Belt tuff (Janoušek et al. 2014), with a small contribution of the Cadomian basement, is in line with the $\mathrm{Nd}$ isotopic considerations (Fig. 11b).

The protolith to the biotite granite should have unradiogenic $\mathrm{Nd}$, be plagioclase-rich and clastic as suggested by numerous rounded xenocrystic zircon cores revealed by CL. The single inherited core measured for $\mathrm{ZU}-3$ yielded a ${ }^{206} \mathrm{~Pb} /{ }^{238} \mathrm{U}$ age of $513 \pm 9 \mathrm{Ma}$ which is in the range of Desná orthogneiss magmatic ages. Indeed, the biotite granite has $\mathrm{Nd}$ isotopic composition overlapping that of the Desná Dome basement composed of metagreywackes and metagranites (Fig. 11b). The direct derivation of the biotite granite from the metagranitic basement is yet precluded as its anatexis would likely produce an A-type granite (Patiño Douce 1997; Hanžl et al. 2007; Janoušek et al. 2014). For that reason, the
Cadomian zircon inheritance rather reflects the fact that (Devonian) greywackes are composed of both Devonian arc-derived detritus and material eroded from the Desná Dome Cadomian basement.

\subsubsection{Toward a plausible model}

Several lines of geological evidence favour an extensional setting at the Carboniferous-Permian transition in the Moravo-Silesian Zone (Cháb et al. 1994; Maluski et al. 1995; Schulmann and Gayer 2000). This regime may have promoted the rise of mantle-related mafic magmas into the relaxing post-orogenic crust, thereby providing a suitable source of heat for crustal melting (Annen et al. 2006; Bea 2012). The mantle heat input would have triggered an anatexis of a deeply buried sequence of inhomogeneous and immature Devonian sedimentary rocks containing arc-derived and Cadomian detritus interbedded with volcaniclastics. The mantle-derived intrusions, and related anatexis of crustal material, probably spanned 5-10 My. The melt extraction episode at $\sim 292$ Ma led to the upper crustal emplacement of the biotite granite, Starost granodiorite and dark granodiorite together with quartz monzodiorite melts.

\subsection{Regional correlation}

\subsubsection{Strzelin Massif}

The intermediate rocks $\left(\mathrm{SiO}_{2}<60 \%\right)$ of the Žulová and Strzelin plutonic associations share trace-element patterns (Fig. 11d) and a shallow level of emplacement (Pietranik and Waight 2008; this study). Strong similarities exist also in $\mathrm{Sr}-\mathrm{Nd}$ isotopic signatures (Žulová: $\varepsilon^{292}{ }_{\mathrm{Nd}}=-2.7$ to $-3.0,{ }^{87} \mathrm{Sr}^{86}{ }^{86} \mathrm{Sr}_{292}=0.7073-0.7076$; Strzelin: $\varepsilon^{300}{ }_{\mathrm{Nd}}=$ -3.0 to $\left.-4.6,{ }^{87} \mathrm{Sr}^{86} \mathrm{Sr}_{300}=0.7065-0.7080\right)($ Fig. 11a) (this work, data of Oberc-Dziedzic et al. 1996, 2010, age-corrected to $300 \mathrm{Ma}$, and those of Pietranik and Waight 2008). Conversely, the trace-element pattern of the biotite granite from the Strzelin Massif, normalized to the average composition of the biotite granite from the Žulová Composite Pluton, shows lower $\mathrm{Nb}$ contents and variable enrichment/depletion in other incompatible trace elements (Fig. 11d). The $\mathrm{Sr}$ isotopic composition of biotite granites from Strzelin $\left({ }^{87} \mathrm{Sr}{ }^{86} \mathrm{Sr}_{300}=0.7063-0.7083\right)$ is also very close to that of the Žulová biotite granite $\left({ }^{87} \mathrm{Sr}^{86}{ }^{86} \mathrm{Sr}_{292}=0.7051-0.7059\right)$.

While the variability in acidic end-members in Žulová and Strzelin may reflect the local mid-crustal compositions, the similarities between intermediate rocks in both plutonic complexes suggest a derivation from a large (at least $70 \mathrm{~km}$ long belt), fairly uniform and fertile reservoir. The existence of such a deep source is likely as both plutons are hosted 
by the same lithotectonic unit consisting of a Carboniferous orogenic wedge. This wedge resulted from the closing of a Devonian arc and back-arc domain developed on the Brunian margin. The distribution of additional small granitic bodies (not shown in Fig. 2), cropping out or known from boreholes between the Žulová Composite Pluton and the Strzelin Massif (Klomínský et al. 2010), indicates a spatially discrete magmatism along the Moldanubian-Brunian terrane boundary (Oberc-Dziedzic et al. 2005).

\subsubsection{The Sudetic Granite Belt}

The four major composite plutons constituting the Sudetic Granite Belt exhibit the same field characteristics (coexisting mafic-felsic magma) and similar $\mathrm{Sr}$ and $\mathrm{Nd}$ isotopic compositions reflecting contribution of both mantle- and crust-derived magmas (Fig. 11a). Their distribution does not seem random but is localized within imbricated crust on periphery of the Teplá-Barrandian and Moldanubian domains. This accumulation of plutons may either be the result of (i) focussed (mantle) heat input along major faults, and/or (ii) localized occurrence of fertile metasedimentary sources at former continental margins. These two conjugate regions are represented by Ordovician oceanic sedimentary wedge thrust onto the Saxothuringian plate in the west and Early-Mid Devonian arc and back-arc domains imbricated with Proterozoic basement of Brunia back stop to the east. The convergence took place during Late Devonian to Early Carboniferous times when the Sudetic orogenic system originated (Mazur et al. 2006). Besides, the widespread presence of an enriched mantle beneath the north-eastern Bohemian Massif is testified by several Late Carboniferous lamprophyre dyke-swarms intruding most of the lithologies, especially in the Moldanubian and TepláBarrandian domains (Awdankiewicz 2007). We point out that the distribution of these dyke-swarms, reflecting the mantle heat input, does not follow the major faults thereby favouring the second hypothesis.

The duration of post-orogenic magmatism at the north-eastern margin of the Bohemian Massif was at least 20 My with an apparent eastward migration from the $\sim 312$ Ma old Krkonoše-Jizera Massif to the $\sim 292 \mathrm{Ma}$ old Žulová Composite Pluton. This timeframe contrasts with the quick assembly of a typical composite pluton (<1 My; e.g. Schoene et al. 2012; Kryza et al. 2014a), demonstrated by liquid-liquid contacts and similar highresolution ID-TIMS ages. Besides, the assignment of unique crystallization age to granites is complicated by the tendency of zircon to keep records of multiple events, including residence in partially molten source. In the Sudetes, numerous recent geochronological studies have been carried out and systematically revealed a zircon record of $\sim 10$ My (Fig. 12) associated with Ar-Ar ages identical, within errors, to the younger $\mathrm{U}-\mathrm{Pb}$ zircon ages (Maluski et al. 1995; Marheine et al. 2002; Turniak et al. 2007). We suggest that the dispersion of $\mathrm{U}-\mathrm{Pb}$ ages is not only analytical or data-treatment artefact but that it may also reflect a protracted anatexis in a deep crustal hot zone. The emplacement of the composite plutons at shallow levels probably reflected episodic magma extraction linked to the reactivation of lithospheric discontinuities at terrane boundaries.

The transition from orogenic to anorogenic settings or from the end of an orogenic phase to the beginning of the next one is a continuum. It is yet not clear whether the thermal energy involved in the generation of the Sudetic granitoids was linked to processes specific to the end of the Variscan Orogeny or whether it heralded a new orogenic cycle/phase. In this respect it is worth noting that the emplacement of the Sudetic Granite Belt was contemporaneous with a major high-T event in the southern Variscan realm interpreted by Schulmann et al. (2014a) as a collision at the Carboniferous-Permian transition.

\section{Conclusions}

Though displaying an apparently continuous trend in major-element compositions from quartz monzodiorite to biotite granite, the Žulová Composite Pluton does not constitute a single differentiation series from the same parental magma. The whole-rock geochemistry and the $\mathrm{Sr}-\mathrm{Nd}$ isotopic data indicate that the source of the biotite granite and the granodiorite could have been an inhomogeneous, arc-derived pile of immature metagreywackes containing variable proportions of Cadomian detritus and interbedded with Devonian volcaniclastics. Quartz monzodiorite may have crystallized from an enriched mantle-derived melt, variably contaminated by a crustal component, most likely the Cadomian basement of the Desná Dome. The magmatic episode probably spanned 5-10 My from source melting to the upper crustal emplacement. The emplacement ages of the biotite granite $(291 \pm 5 \mathrm{Ma})$, Starost granodiorite, dark granodiorite and quartz monzodiorite $(292 \pm 4 \mathrm{Ma})$ were within the error identical.

The Žulová Composite Pluton intruded during a regional-scale event along with additional three plutonic complexes composing the Sudetic Granite Belt: the Krkonoše-Jizera, the Strzegom-Sobótka and the Strzelin massifs. The extensional regime prevailing in the Variscan realm at the Carboniferous-Permian transition may have promoted the rise of mantle-related mafic magmas into the relaxing post-orogenic crust thereby triggering mid-crustal anatexis. The emplacement of composite plutons at shallow levels was subsequently related to the reactivation of lithospheric discontinuities at terrane boundaries. 


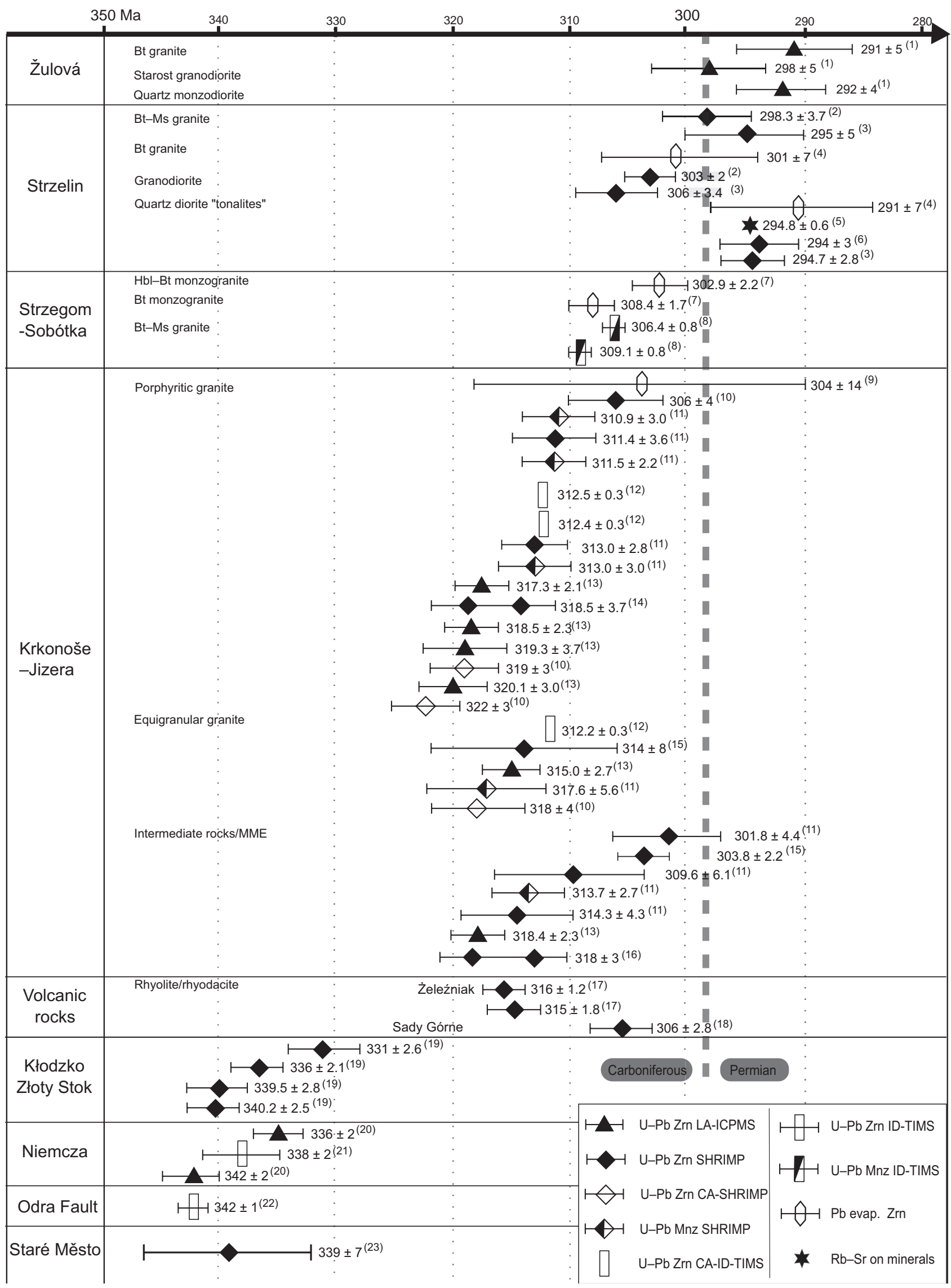


Taken together, this study documents that in a postorogenic setting, mantle-derived melts may display isotopically more evolved signatures than immature crustal sources. Former orogenic wedges, resulting from the inversion of youthful plate margins, represent a feasible source for such post-orogenic granitoids.

Acknowledgements. We are grateful to Josef Klomínský for stimulating discussions and Vratislav Pecina for continuous logistic support in the field. Alexey Ulianov is thanked for his help during LA-ICP-MS analyses. We also acknowledge Z. Korbelová for assistance during the microprobe analyses. Ryszard Kryza and an anonymous reviewer are thanked for their critical comments. Editorial handling by Friedrich Finger was greatly appreciated. A.L. benefited from Erasmus grant of the European Union and Boussole grant of the Région Alsace for his stay at the Czech Geological Survey in 2013. This is the contribution to the LK11202 program of the Ministry of Education of the Czech Republic (to KS).

Electronic supplementary material. Analytical details, U$\mathrm{Pb}$ isotopic data from dated zircons, petrographic descriptions and review of the previously published major- and trace-element analyses from the Žulová Composite Pluton are available online at the Journal web site (http://dx.doi. org/10.3190/jgeosci.176).

\section{References}

Aleksandrowski P, Kryza R, Mazur S, Źaba J (1997) Kinematic data on major Variscan strike-slip faults and shear zones in the Polish Sudetes, northeast Bohemian Massif. Geol Mag 134: 727-739

Annen C, Blundy JD, Sparks RSJ (2006) The genesis of intermediate and silicic magmas in deep crustal hot zones. J Petrol 47: 505-539

Fig. 12 - Compilation of published U-Pb ages of selected Variscan granitoids from the north-eastern Bohemian Massif. Data sources: (1) this study, (2) Oberc-Dziedzic et al. (2013), (3) Oberc-Dziedzic and Kryza (2012), (4) Turniak et al. (2005a), (5) Pietranik and Waight (2008), (6) Oberc-Dziedzic et al. (2010), (7) Turniak et al. (2005b), (8) Turniak and Bröcker (2002), (9) Kröner et al. (1994), (10) Kryza et al. (2012), (11) Kusiak et al. (2014), (12) Kryza et al. (2014a), (13) Žák et al. (2013), (14) Machowiak and Armstrong (2007), (15) Kusiak et al. (2009), (16) Awdankiewicz et al. (2010), (17) Machowiak et al. (2008), (18) Kryza and Awdankiewicz (2012), (19) Mikulski et al. (2013), (20) Pietranik et al. (2013), (21) Oliver et al. (1993), (22) Dörr et al. (2006), (23) Parry et al. (1997). The thick dashed line denotes the Carboniferous/Permian boundary, following Cohen et al. (2013). LA: Laser Ablation, ICP-MS: Inductively Coupled Plasma Mass Spectrometry, SHRIMP: Sensitive High Resolution Ion MicroProbe, CA: Chemical Abrasion, ID-TIMS: Isotope Dilution Thermal-Ionization Mass Spectrometry.
Awdankiewicz M (2004) Sedimentation, volcanism and subvolcanic intrusions in a late Palaeozoic intramontane trough (the Intra-Sudetic Basin, SW Poland). In: BREITKreuz C, Petford N (eds) Physical Geology of HighLevel Magmatic Systems. Geological Society London Special Publications 234: 5-11

Awdankiewicz M (2007) Late Palaeozoic lamprophyres and associated mafic subvolcanic rocks of the Sudetes (SW Poland): petrology, geochemistry and petrogenesis. Geol Sudetica 39: 11-97

Awdankiewicz M, Awdankiewicz H, Kryza R, Rodionov N (2010) SHRIMP zircon study of a micromonzodiorite dyke in the Karkonosze Granite, Sudetes (SW Poland): age constraints for late Variscan magmatism in Central Europe. Geol Mag 147: 77-85

Baratoux L, Lexa O, Cosgrove JW, Schulmann K (2005) The quantitative link between fold geometry, mineral fabric and mechanical anisotropy: as exemplified by the deformation of amphibolites across a regional metamorphic gradient. J Struct Geol 27: 707-730

BARBarin B, Didier J (1992) Genesis and evolution of mafic microgranular enclaves through various types of interaction between coexisting felsic and mafic magmas. Trans Roy Soc Edinb, Earth Sci 83: 145-153

BEA F (2012) The sources of energy for crustal melting and the geochemistry of heat-producing elements. Lithos 153: 278-291

Blundy JD, Shimizu N (1991) Trace element evidence for plagioclase recycling in calc-alkaline magmas. Earth Planet Sci Lett 102: 178-197

Bonin B (2004) Do coeval mafic and felsic magmas in post-collisional to within-plate regimes necessarily imply two contrasting, mantle and crustal, sources? A review. Lithos 78: 1-24

Bonin B, Azzouni-Sekkal A, Bussy F, Ferrag S (1998) Alkali-calcic and alkaline post-orogenic (PO) granite magmatism: petrologic constraints and geodynamic settings. Lithos 45: 45-70

Boynton WV (1984) Cosmochemistry of the rare earth elements: meteorite studies. In: Henderson P (ed) Rare Earth Element Geochemistry. Elsevier, Amsterdam, pp 63-114

СНÁB J, ŽÁ̌̌EK V (1994) Geology of the Žulová pluton mantle (Bohemian Massif, Central Europe). Věst Čes Geol Úst 69: 1-12

СhÁB J, MiXA P, VANĚČEK M, ŽÁČEK V (1994) Evidence of an extensional tectonics in the NW of the Hrubý Jeseník Mts (the Bohemian Massif, Central Europe). Věst Čes Geol Úst 69: 7-16

Chopin F, Schulmann K, Skrzypek E, Lehmann J, Dujardin JR, Martelat JE, Lexa O, Corsini M, Edel JB, Štípská $P$ (2012) Crustal influx, indentation, ductile thinning and gravity redistribution in a continental wedge: building a Moldanubian mantled gneiss dome with underthrust 
Saxothuringian material (European Variscan belt). Tectonics 31: TC1013. doi: 10.1029/2011TC002951

Cohen KM, Finney SM, Gibbard PL, Fan J-X (2013) The ICS International Chronostratigraphic Chart. Episodes 36: 199-204

Collins AS, Kryza R, Zalasiewicz J (2000) Macrofabric fingerprints of Late Devonian-Early Carboniferous subduction in the Polish Variscides, the Kaczawa Complex, Sudetes. J Geol Soc, London 157: 283-288

Conticelli S, Guarnieri L, Farinelli A, Mattei M, Avanzinelli R, Bianchini G, Boari E, Tommasini S, Tiepolo M, Prelević D (2009) Trace elements and Sr-Nd- $\mathrm{Pb}$ isotopes of K-rich, shoshonitic, and calc-alkaline magmatism of the Western Mediterranean Region: genesis of ultrapotassic to calc-alkaline magmatic associations in a post-collisional geodynamic setting. Lithos 107: 68-92

Corfu F, Hanchar JM, Hoskin PW, Kinny P (2003) Atlas of zircon textures. In: HANCHAR JM, Hoskin PWO (eds) Zircon. Mineralogical Society of America and Geochemical Society Reviews in Mineralogy and Geochemistry 53: 469-500

Cox KG, Bell JD, Pankhurst RJ (1979) The Interpretation of Igneous Rocks. Allen \& Unwin, London, pp 1-450

Čadková Z, Jakeš P, Haková M, Mrázek P (1985) Geochemical catalogue of the basic network. Unpublished manuscript, Czech Geological Survey, Prague. In: Lithogeochemical database of the Czech Geological Survey (in Czech)

DeBOn F, Le Fort P (1983) A chemical-mineralogical classification of common plutonic rocks and associations. Trans Roy Soc Edinb, Earth Sci 73: 135-149

De Paolo DJ (1981) Trace-element and isotopic effects of combined wallrock assimilation and fractional crystallization. Earth Planet Sci Lett 53: 189-202

DomaŃSKA-SiudA J (2007) The granitoid Strzegom-Sobótka Massif. In: KozLowski A, WiszniewsKa J (eds) Granitoids in Poland. Arch Miner Monogr 1, Warsaw, pp 179-191

Don J, Skácel J, Gotowaza R (2003) The boundary zone of the East and West Sudetes on the 1: 50000 scale geological map of the Velké Vrbno, Staré Město and Śnieżnik metamorphic units. Geol Sudetica 35: 25-59

Dörr W, Żelaźniewicz A, Bylina P, Schastok J, Franke W, HAACK U, KULICKI C (2006) Tournaisian age of granitoids from the Odra Fault Zone (southwestern Poland): equivalent of the Mid-German Crystalline High? Int J Earth Sci 95: 341-349

Dudek A (1980) The crystalline basement block of the Outer Carpathians in Moravia: BrunoVistulicum. Rozpr Čs Akad Věd, ř mat přír Věd 90: 3-85

Dziedzic K, Teisseyre AK (1990) The Hercynian molasse and younger deposits in the Intra-Sudetic Depression, SW Poland. Neu Jb Geol Paläont, Abh 179: 285-305

Edel JB, Schulmann K, Skrzypek E, Cocherie A (2013) Tectonic evolution of the European Variscan belt constrained by palaeomagnetic, structural and anisotropy of magnetic susceptibility data from the Northern Vosges magmatic arc (eastern France). J Geol Soc, London 170: 785-804

FARYAD SW, KACHLíK V (2013) New evidence of blueschist facies rocks and their geotectonic implication for Variscan suture(s) in the Bohemian Massif. J Metamorph Geol 31: 63-82

Finger F, Roberts MP, Haunschmid B, Schermaier A, SteyRER HP (1997) Variscan granitoids of central Europe: their typology, potential sources and tectonothermal relations. Mineral Petrol 61: 67-96

Finger F, Gerdes A, René M, Riegler G (2009) The SaxoDanubian Granite Belt: magmatic response to postcollisional delamination of mantle lithosphere below the southwestern sector of the Bohemian Massif (Variscan orogen). Geol Carpath 60: 205-212

FÖRSTER HJ, ROMER RL (2010) Carboniferous magmatism. In: LinNEMANN U, Romer RL (eds) The pre-Mesozoic Geology of Saxo-Thuringia (NW Bohemian Massif) - From the Cadomian Active Margin to the Variscan Orogen. Schweizerbart Science Publishers, Stuttgart, pp 287-308

Franke W (2000) The mid-European segment of the Variscides: tectonostratigraphic units, terrane boundaries and plate tectonic evolution. In: FranKe W, HAAK V, ONCKEN O, TANNER D (eds) Orogenic Processes: Quantification and Modelling in the Variscan Belt. Geological Society London Special Publications 179: pp 35-61

Goldstein SL, O'Nions RK, Hamilton PJ (1984) A Sm-Nd isotopic study of atmospheric dusts and particulates from major river systems. Earth Planet Sci Lett 70: 221-236

HANCHAR JM, WATSON EB (2003) Zircon saturation thermometry. In: Hanchar JM, Hoskin PWO (eds) Zircon. Mineralogical Society of America and Geochemical Society Reviews in Mineralogy and Geochemistry 53: 89-112

Hanson GN, Langmuir CH (1978) Modelling of major elements in mantle-melt systems using trace element approaches. Geochim Cosmochim Acta 42: 725-741

HanžL P, JanoušEk V, ŽÁčé V, WilimskÝ D, Aichler J, Erban V, Pudilová M, Chlupáčová M, Buriánková K, Mixa P (2007) Magmatic history of granite-derived mylonites from the southern Desná Unit (Silesicum, Czech Republic). Mineral Petrol 89: 45-75

Harris NBW, Pearce JA, Tindle AG (1986) Geochemical characteristics of collision-zone magmatism. In: COWARD MP, Alison C (eds) Collision Tectonics. Geological Society London Special Publications 19: 67-81

Hegner E, KRÖNer A (2000) Review of Nd isotopic data and xenocrystic and detrital zircon ages from the preVariscan basement in the eastern Bohemian Massif: speculations on palinspastic reconstructions. In: FranKE W, HaAk V, Oncken O, Tanner D (eds) Orogenic processes: quantification and modelling in the Variscan Fold Belt. Geological Society London Special Publications 179: 113-129 
ICENHOWER J, LONDON D (1996) Experimental partitioning of $\mathrm{Rb}, \mathrm{Cs}, \mathrm{Sr}$, and $\mathrm{Ba}$ between alkali feldspar and peraluminous melt. Amer Miner 81: 719-734

Irvine T, BARAGAR W (1971) A guide to the chemical classification of the common volcanic rocks. Can J Earth Sci 8: 523-548

IsHIHARA $S$ (1981) The granitoid series and mineralization. Econ Geol $75^{\text {th }}$ Anniversary Volume: 458-484

JaCobSen SB, WasSerburg GJ (1980) Sm-Nd isotopic evolution of chondrites. Earth Planet Sci Lett 50: 139-155

JANOUŠEK V (2006) Saturnin, R language script for application of accessory-mineral saturation models in igneous geochemistry. Geol Carpath 57: 131-142

JANOUŠEK V, HoLUB FV (2007) The causal link between HPHT metamorphism and ultrapotassic magmatism in collisional orogens: case study from the Moldanubian Zone of the Bohemian Massif. Proc Geol Assoc 118: 75-86

JaNoušEK V, Rogers G, Bowes DR (1995) Sr-Nd isotopic constraints on the petrogenesis of the Central Bohemian Pluton, Czech Republic. Geol Rundsch 84: 520-534

Janoušek V, Aichler J, Hanžl P, Gerdes A, Erban V, Žáček V, Pecina V, Pudilová M, HrdličKová K, Mixa P, ŽÁČKOVÁ E (2014) Constraining genesis and geotectonic setting of metavolcanic complexes: a multidisciplinary study of the Devonian Vrbno Group (Hrubý Jeseník Mts., Czech Republic). Int J Earth Sci 103: 455-483

Jung S, Masberg P, Mihm D, Hoernes S (2009) Partial melting of diverse crustal sources - constraints from $\mathrm{Sr}-\mathrm{Nd}-\mathrm{O}$ isotope compositions of quartz diorite-granodiorite-leucogranite associations (Kaoko Belt, Namibia). Lithos 111: 236-251

Kalvoda J, Bábek O, Fatka O, Leichmann J, Melichar R, Nehyba S, ŠpaČEK P (2008) Brunovistulian Terrane (Bohemian Massif, Central Europe) from late Proterozoic to late Paleozoic: a review. Int J Earth Sci 97: 497-518

Kemp Ais, Hawkesworth CJ, Foster GL, Paterson BA, Woodhead JD, Hergt JM, Gray CM, Whitehouse MJ (2007) Magmatic and crustal differentiation history of granitic rocks from Hf-O isotopes in zircon. Science 315: 980-983

KlomínskÝ J, JaRchovskÝ T, RaJPOOT G (2010) Atlas of Plutonic Rocks and Orthogneisses in the Bohemian Massif: Brunovistulicum and Moravosilesicum. Czech Geological Survey, Prague, pp 40-45

KoŠULIČOVÁ M, ŠTíPSKÁ P (2007) Variations in the transient prograde geothermal gradient from chloritoid-staurolite equilibria: a case study from the Barrovian and Buchantype domains in the Bohemian Massif. J Metamorph Geol 25: 19-35

KRONER U, ROMER RL (2013) Two plates - many subduction zones: the Variscan orogeny reconsidered. Gondwana Res 24: 298-329

Kröner A, Hegner E, Hammer J, Haase G, Bielicki K-H, Krauss M, EidAm J (1994) Geochronology and Nd-Sr systematics of Lusatian granitoids: significance for the evolution of the Variscan orogen in east-central Europe. Geol Rundsch 83: 357-376

Kröner A, Štípská P, Schulmann K, Jaeckel P (2000) Chronological constraints on the pre-Variscan evolution of the northeastern margin of the Bohemian Massif, Czech Republic. In: Franke W, HaAk V, Oncken O, TANNER D (eds) Orogenic Processes: Quantification and Modelling in the Variscan Fold Belt. Geological Society London Special Publications 179: 175-197

Kryza R, AwDANKIEwicz M (2012) Ambiguous geological position of Carboniferous rhyodacites in the Intra-Sudetic Basin (SW Poland) clarified by SHRIMP zircon ages. Geol Quart 56: 55-66

Kryza R, PIN C (2010) The Central-Sudetic ophiolites (SW Poland): petrogenetic issues, geochronology and palaeotectonic implications. Gondwana Res 17: 292-305

Kryza R, Zalasiewicz J, Mazur S, Aleksandrowski P, Sergeev S, Larionov A (2007) Precambrian crustal contribution to the Variscan accretionary prism of the Kaczawa Mountains (Sudetes, SW Poland): evidence from SHRIMP dating of detrital zircons. Int J Earth Sci 96: 1153-1162

Kryza R, Crowley QG, Larionov A, Pin C, Oberc-Dziedzic T, Mochnacka K (2012) Chemical abrasion applied to SHRIMP zircon geochronology: an example from the Variscan Karkonosze Granite (Sudetes, SW Poland). Gondwana Res 21: 757-767

Kryza R, Schaltegger U, Oberc-Dziedzic T, Pin C, OvtchaROVA M (2014a) Geochronology of a composite granitoid pluton: a high-precision ID-TIMS U-Pb zircon study of the Variscan Karkonosze Granite (SW Poland). Int J Earth Sci 103: 683-696

Kryza R, Pin C, Oberc-Dziedzic T, Crowley QG, Larionov A (2014b) Deciphering the geochronology of a large granitoid pluton (Karkonosze Granite, SW Poland): an assessment of $\mathrm{U}-\mathrm{Pb}$ zircon SIMS and $\mathrm{Rb}-\mathrm{Sr}$ whole-rock dates relative to $\mathrm{U}-\mathrm{Pb}$ zircon CA-ID-TIMS. Int Geol Rev 56: 756-782

Kusiak MA, Dunkley DJ, SŁaby E, Martin H, Budzyń B (2009) Sensitive high-resolution ion microprobe analysis of zircon reequilibrated by late magmatic fluids in a hybridized pluton. Geology 37: 1063-1066

Kusiak MA, Williams IS, Dunkley DJ, KoneČNÝ P, SŁaby E, Martin H (2014) Monazite to the rescue: U-Th-Pb dating of the intrusive history of the composite Karkonosze Pluton, Bohemian Massif. Chem Geol 364: 76-92

Lardeaux JM, Schulmann K, Faure M, Janoušek V, Lexa O, Skrzypek E, Edel JB, ŠTí́sská P (2014) The Moldanubian Zone in French Massif Central, Vosges/Schwarzwald and Bohemian Massif revisited: differences and similarities. In: Schulmann K, Martínez Catalán JR, Lardeaux JM, Janoušek $V$, Oggiano $G$ (eds) The Variscan Orogeny: Extent, Timescale and the Formation of 
the European Crust. Geological Society London Special Publications 405: pp 7-44

LAURENT A (2013) Géochimie et géochronologie du magmatisme de type-I tardi-Carbonifère de la marge Nord-est du Massif de Bohême: implications géodynamiques. Unpublished MSci Thesis, Université de Strasbourg, pp 1-32

Liégeois J-P, Navez J, Hertogen J, Black R (1998) Contrasting origin of post-collisional high-K calc-alkaline and shoshonitic versus alkaline and peralkaline granitoids. The use of sliding normalization. Lithos 45: 1-28

Liew TC, Hofmann AW (1988) Precambrian crustal components, plutonic associations, plate environment of the Hercynian Fold Belt of central Europe: indications from a Nd and Sr isotopic study. Contrib Mineral Petrol 98: 129-138

Machowiak K, Armstrong R (2007) SHRIMP U-Pb zircon age from the Karkonosze granite. Miner Pol Spec Pap 31: 193-196

Machowiak K, Armstrong R, Kryza R, MuszyŃski A (2008) Late-orogenic magmatism in the central European Variscides: SHRIMP U-Pb zircon age constraints from the Zelaźniak Intrusion, Kaczawa Mountains, West Sudetes. Geol Sudetica 40: 1-18

Maluski H, PatoČKa F (1997) Geochemistry and ${ }^{40} \mathrm{Ar} /{ }^{39} \mathrm{Ar}$ geochronology of the mafic metavolcanic rocks from the Rýchory Mountains complex (west Sudetes, Bohemian Massif): palaeotectonic significance. Geol Mag 134: 703-716

Maluski H, Rajlich P, Souček J (1995) Pre-Variscan, Variscan and Early Alpine thermo-tectonic history of the north-eastern Bohemian Massif: an ${ }^{40} \mathrm{Ar} /{ }^{39} \mathrm{Ar}$ study. Geol Rundsch 84: 345-358

Marheine D, Kachlík V, Maluski H, PatočKa F, Żelaźniewicz A (2002) $\mathrm{The}^{40} \mathrm{Ar}{ }^{39} \mathrm{Ar}$ ages from the West Sudetes (NE Bohemian Massif): constraints on the Variscan polyphase tectonothermal development. In Winchester JA, PhAraOH TC, Verniers J (eds) Palaeozoic Amalgamation of Central Europe. Geological Society of London Special Publications 201: 133-155

MATte P (1991) Accretionary history and crustal evolution of the Variscan belt in western Europe. Tectonophysics 196: 309-337

Mazur S, Aleksandrowski P, Kryza R, Oberc-Dziedzic T (2006) The Variscan Orogen in Poland. Geol Q 50: $89-118$

Mazur S, Szczepański J, Turniak K, McNaughton NJ (2012) Location of the Rheic suture in the eastern Bohemian Massif: evidence from detrital zircon data. Terra Nova 24: 199-206

Míxová J, Denková P (2007) Modified chromatographic separation scheme for $\mathrm{Sr}$ and $\mathrm{Nd}$ isotope analysis in geological silicate samples. J Geosci 52: 221-226

Mikulski SZ, Williams IS, BagiŃSki B (2013) Early Carboniferous (Viséan) emplacement of the collisional
Kłodzko-Złoty Stok granitoids (Sudetes, SW Poland): constraints from geochemical data and zircon $\mathrm{U}-\mathrm{Pb}$ ages. Int J Earth Sci 102: 1007-1027

Miller C, Schuster R, Klötzli U, Frank W, Purtscheller F (1999) Post-collisional potassic and ultrapotassic magmatism in SW Tibet: geochemical and $\mathrm{Sr}-\mathrm{Nd}-\mathrm{Pb}-\mathrm{O}$ isotopic constraints for mantle source characteristics and petrogenesis. J Petrol 40: 1399-1424

Miller CF, McDowell SM, Mapes RW (2003) Hot and cold granites? Implications of zircon saturation temperatures and preservation of inheritance. Geology 31 : $529-532$

Miller JS, Matzel Je, Miller CF, Burgess SD, Miller RB (2007) Zircon growth and recycling during the assembly of large, composite arc plutons. J Volcanol Geotherm Res 167: 282-299

Oberc-Dziedzic T (1999) The geology of the Strzelin granitoids (Fore-Sudetic Block, SW Poland). Miner Pol Spec Pap 14: 22-32

Oberc-Dziedzic T, Kryza R (2012) Late stage Variscan magmatism in the Strzelin Massif(SW Poland): SHRIMP zircon ages of tonalite and $\mathrm{Bt}-\mathrm{Ms}$ granite of the Gęsiniec intrusion. Geol Q 56: 225-236

Oberc-Dziedzic T, Pin C, Duthou JL, Couturie JP (1996) Age and origin of the Strzelin granitoids (Fore-Sudetic Block, Poland): ${ }^{87} \mathrm{Rb} \_-{ }^{87} / \mathrm{Sr}$ data. Neu Jb Mineral, Abh 171: $187-198$

Oberc-Dziedzic T, Kryza R, Klimas K, Fanning M, Madej S (2005) Gneiss protolith ages and tectonic boundaries in the NE part of the Bohemian Massif (Fore-Sudetic Block, SW Poland). Geol Q 49: 363-378

Oberc-Dziedzic T, Kryza R, Biatek J (2010) Variscan multistage granitoid magmatism in Brunovistulicum: petrological and SHRIMP U-Pb zircon geochronological evidence from the southern part of the Strzelin Massif, SW Poland. Geol Q 54: 301-324

Oberc-Dziedzic T, Kryza R, Pin C, Madej S (2013) Variscan granitoid plutonism in the Strzelin Massif (SW Poland): petrology and age of the composite Strzelin granite intrusion. Geol Q 57: 269-288

Oliver GJH, Corfu F, Krogh TE (1993) U-Pb ages from SW Poland: evidence for a Caledonian suture zone between Baltica and Gondwana. J Geol Soc, London 150: 355-369

Parry M, Štípská P, Schulmann K, Hrouda F, Ježek J, KRÖNER A (1997) Tonalite sill emplacement at an oblique plate boundary: northeastern margin of the Bohemian Massif. Tectonophysics 280: 61-81

Patiño Douce AE (1997) Generation of metaluminous Atype granites by low-pressure melting of calc-alkaline granitoids. Geology 25: 743-746

PatiÑo Douce AE (1999) What do experiments tell us about the relative contributions of crust and mantle to the origin of granitic magmas? In: CASTRo A, Fernandez C, VigN- 
ERESSE JL (eds) Understanding Granites: Integrating New and Classical Techniques. Geological Society of London Special Publications 168: 55-75

Pearce JA, Peate DW (1995) Tectonic implications of the composition of volcanic arc magmas. Ann Rev Earth Planet Sci 23: 251-286

Pearce JA, Harris NB, Tindle AG (1984) Trace element discrimination diagrams for the tectonic interpretation of granitic rocks. J Petrol 25: 956-983

Peccerillo A, Taylor SR (1976) Geochemistry of Eocene calc-alkaline volcanic rocks from the Kastamonu area, northern Turkey. Contrib Mineral Petrol 58: 63-81

Pecina V, Čurda J, Hanáček M, KoČandrle J, Nývlt D, Opletal M, Skácelová D, SkÁcelová Z, VeČeřa J, Ž́áček V (2006) Explanations to the basic geological map of the Czech Republic 1:25 000, sheet 14-221 Žulová. Unpublished manuscript, Czech Geological Survey, Prague, pp 1-108 (in Czech)

Pietranik A, Koepke J (2009) Interactions between dioritic and granodioritic magmas in mingling zones: plagioclase record of mixing, mingling and subsolidus interactions in the Gęsiniec Intrusion, NE Bohemian Massif, SW Poland. Contrib Mineral Petrol 158: 17-36

Pietranik A, Waight TE (2008) Processes and sources during Late Variscan dioritic-tonalitic magmatism: insights from plagioclase chemistry (Gęsiniec Intrusion, NE Bohemian Massif, Poland). J Petrol 49: 1619-1645

Pietranik A, Koepke J, Puziewicz J (2006) Crystallization and resorption in plutonic plagioclase: implications on the evolution of granodiorite magma (Gęsiniec granodiorite, Strzelin Crystalline Massif, SW Poland). Lithos 86: $260-280$

Pietranik A, Storey C, Dhuime B, Tyszka R, Whitehouse M (2011) Decoding whole rock, plagioclase, zircon and apatite isotopic and geochemical signatures from variably contaminated dioritic magmas. Lithos 127: 455-467

Pietranik A, Storey C, Kierczak J (2013) Niemcza diorites and monzodiorites (Sudetes, SW Poland): a record of changing geotectonic setting at ca. $340 \mathrm{Ma}$. Geol Q 57: 325-334

Pin C, Puziewicz J, Duthou JL (1989) Ages and origins of a composite granitic massif in the Variscan Belt - $\mathrm{a} \mathrm{Rb}-$ Sr study of the Strzegom-Sobótka Massif, W Sudetes (Poland). Neu Jb Mineral, Abh 160: 71-82

Ridolfi F, Renzulli A (2012) Calcic amphiboles in calcalkaline and alkaline magmas: thermobarometric and chemometric empirical equations valid up to $1,130^{\circ} \mathrm{C}$ and 2.2 GPa. Contrib Mineral Petrol 163: 877-895

Schandl ES, Gorton MP (2002) Application of high field strength elements to discriminate tectonic settings in VMS environments. Econ Geol 97: 629-642

ScharfF P (1920) Petrographische Studien im Granitodioritischen Eruptivgebiet von Friedberg in Österr. Schlesien. V Grass \& Comp, Breslau, pp 1-55
Schoene B, Schaltegger U, Brack P, Latkoczy C, Stracke A, GÜNTHER D (2012) Rates of magma differentiation and emplacement in a ballooning pluton recorded by $\mathrm{U}-\mathrm{Pb}$ TIMS-TEA, Adamello Batholith, Italy. Earth Planet Sci Lett 355: 162-173

Schulmann K, Gayer R (2000) A model for a continental accretionary wedge developed by oblique collision: the NE Bohemian Massif. J Geol Soc, London 157: 401-416

Schulmann K, Konopásek J, Janoušek V, Lexa O, Lardeaux JM, Edel JB, ŠTí́skÁ P, UlRich S (2009) An Andean type Palaeozoic convergence in the Bohemian Massif. C R Geosci 341: 266-286

Schulmann K, Martínez Catalán JR, Lardeaux JM, Janoušek V, OgGiano G (eds) (2014a) The Variscan orogeny: extent, timescale and the formation of the European crust (Introduction). Geological Society of London Special Publications 405: 1-6

Schulmann K, Lexa O, Janoušek V, Lardeaux JM, Edel JB (2014b) Anatomy of a diffuse cryptic suture zone: an example from the Bohemian Massif, European Variscides. Geology 42: 275-278

Schulmann K, Oliot E, Košuličová M, Montigny R, ŠTíPSKÁ P, KRÖNER A (2014c) Variscan thermal overprints exemplified by $\mathrm{Th}-\mathrm{U}-\mathrm{Pb}$ monazite and $\mathrm{K}-\mathrm{Ar}$ mica dating at the eastern margin of the Bohemian Massif (West Sudetes, Czech Republic). J Geosci 59: X-Y

Siebel W, Chen F, Satir M (2003) Late-Variscan magmatism revisited: new implications from $\mathrm{Pb}$-evaporation zircon ages on the emplacement of redwitzites and granites in NE Bavaria. Int J Earth Sci 92: 36-53

Skrzypek E, Tabaud AS, Edel JB, Schulmann K, CoCherie A, Guerrot C, Rossi P (2012) The significance of Late Devonian ophiolites in the Variscan orogen: a record from the Vosges Klippen Belt. Int J Earth Sci 101: 951-972

Staby E, Martin H (2008) Mafic and felsic magma interaction in granites: the Hercynian Karkonosze Pluton (Sudetes, Bohemian Massif). J Petrol 49: 353-391

Stacey JT, Kramers JD (1975) Approximation of terrestrial lead isotope evolution by a two-stage model. Earth Planet Sci Lett 26: 207-221

Sun SS, McDonough W (1989) Chemical and isotopic systematics of oceanic basalts: implications for mantle composition and processes. In: SAUnders AD, Norry M (eds) Magmatism in the Ocean Basins. Geological Society of London Special Publications 42: 313-345

Sylvester PJ (1989) Post-collisional alkaline granites. J Geol 97: 261-280

SylveSter PJ (1998) Post-collisional strongly peraluminous granites. Lithos 45: 29-44

SzCZEPAŃSKI J (2007) A vestige of an Early Devonian active continental margin in the East Sudetes (SW Poland) - evidence from geochemistry of the Jegłowa Beds, Strzelin Massif. Geol Quart 51: 271-284 
ŠTíPSKÁ P, Pitra P, Powell R (2006) Separate or shared metamorphic histories of eclogites and surrounding rocks? An example from the Bohemian Massif. J Metamorph Geol 24: 219-240

TAKAGI T (2004) Origin of magnetite- and ilmenite-series granitic rocks in the Japan arc. Amer J Sci 304: 169-202

Tera F, Wasserburg GJ (1972) U-Th-Pb systematics in three Apollo 14 basalts and the problem of initial $\mathrm{Pb}$ in lunar rocks. Earth Planet Sci Lett 14: 281-304

Turner S, SAndiford M, Foden J (1992) Some geodynamic and compositional constraints on postorogenic magmatism. Geology 20: 931-934

TURNIAK K, BRÖCKER M (2002) Age of the two-mica granite from the Strzegom-Sobótka Massif: new data from U/ $\mathrm{Pb}$ monazite and xenotime study. Miner Pol Spec Pap 20: 211-213

Turniak K, Tichomirowa M, Bombach K (2005a) Pbevaporation zircon ages of post-tectonic granitoids from the Strzelin Massif (SW Poland). Miner Pol Spec Pap 29: 212-215

Turniak K, Tichomirowa M, Bombach K (2005b) Zircon $\mathrm{Pb}$-evaporation ages of granitoids from the StrzegomSobótka Massif (SW Poland). Miner Pol Spec Pap 29: 241-245

Turniak K, Halas S, Wójtowicz A (2007) New K-Ar cooling ages of granitoids from the Strzegom-Sobótka Massif, SW Poland. Geochronometria 27: 5-9

Van Breemen O, Aftalion M, Bowes DR, Dudek A, Mísař Z, Povondra P, VRÁnA S (1982) Geochronological studies of the Bohemian Massif, Czechoslovakia, and their significance in the evolution of Central Europe. Trans Roy Soc Edinb, Earth Sci 73: 89-108

Vegas N, Rodriguez J, Cuevas J, Siebel W, Esteban JJ, TubíA JM, BASEI M (2011) The sphene-centered ocellar texture: an effect of grain-supported flow and melt migration in a hyperdense magma mush. J Geol 119: 143-157

WATSON EB, HARRISON TM (1983) Zircon saturation revisited: temperature and composition effects in a variety of crustal magma types. Earth Planet Sci Lett 64: 295-304

Wiebe RA, Collins WJ (1998) Depositional features and stratigraphic sections in granitic plutons: implications for the emplacement and crystallization of granitic magma. J Struct Geol 20: 1273-1289

Willbold M, Stracke A (2010) Formation of enriched mantle components by recycling of upper and lower continental crust. Chem Geol 276: 188-197

Wood DA (1980) The application of a Th-Hf-Ta diagram to problems of tectonomagmatic classification and to es- tablishing the nature of crustal contamination of basaltic lavas of the British Tertiary Volcanic Province. Earth Planet Sci Lett 50: 11-30

Zachovalová K, Leichmann J, Švancara J (2002) Žulová Batholith: a post-orogenic, fractionated ilmenite-allanite I-type granite. J Geosci 47: 35-44

Žáček V, Čurda J, KoČandrle J, Nekovařík Č, NÝvlt D, Pecina V, Skácelová D, Skácelová Z, Večeřa J (2004a) Basic map of the Czech Republic 1: 25 000, sheet 14-222 Vidnava. Czech Geological Survey, Prague (in Czech)

Žáček V, Čurda J, Kočandrle J, Nývlt D, Pecina V, Nekovařík Č, Skácelová D, Skácelová Z, VeČeřa J (2004b) Explanations to the basic map of the Czech Republic 1: 25 000, sheet 14-222 Vidnava. Czech Geological Survey, Prague, pp 1-45 (in Czech)

ŽÁČEK V, NÝVLT D, MiXA P (2005a) Basic geological map of the Czech Republic 1:25 000, sheet 14-223 Lipová Lázně. Czech Geological Survey, Prague (in Czech)

Žáček V, Čurda J, Kočandrle J, NÝvlt D, Pecina V, Skácelová D, Skácelová Z, Sulovský P, VeČeřa J (2005b) Explanations to the basic geological map of the Czech Republic 1:25 000, sheet 14-223 Lipová Lázně. Czech Geological Survey, Prague, pp 1-108 (in Czech)

ŽÁčKová E, KonopÁsek J, JeřÁBeK P, Finger F, KošLer J (2010) Early Carboniferous blueschist facies metamorphism in metapelites of the West Sudetes (northern Saxothuringian Domain, Bohemian Massif). J Metamorph Geol 28: 361-379

ŽÁk J, Verner K, Sláma J, Kachlík V, Chlupáčová M (2013) Multistage magma emplacement and progressive strain accumulation in the shallow-level Krkonoše--Jizera Plutonic Complex, Bohemian Massif. Tectonics 32: 1493-1512

ŽÁk J, Verner K, Janoušek V, Holub FV, Kachlík V, Finger F, Hajná J, Tomek F, Vondrovic L, Trubač J (2014) A plate-kinematic model for the assembly of the Bohemian Massif constrained by structural relationships around granitoid plutons. In: Schulmann K, MartíneZ Catalán JR, Lardeaux JM, Janoušek V, Oggiano G (eds) The Variscan orogeny: Extent, Timescale and the Formation of the European Crust. Geological Society of London Special Publications 405: 169-196

ŻElaźniewicz A, NowAK I, BACHLiński R, LARIONOV AN, SergeEv SA (2005) Cadomian versus younger deformations in the basement of the Moravo-Silesian Variscides, East Sudetes, SW Poland: U-Pb SHRIMP and Rb-Sr age data. Geol Sudetica 37: 35-51 